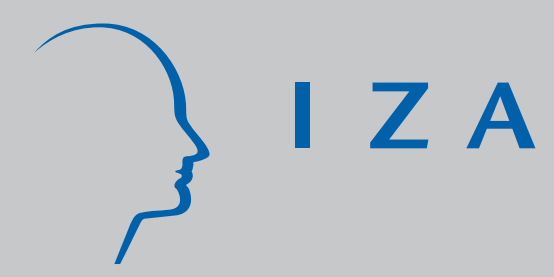

IZA DP No. 3752

Two to Tangle: Financial Development, Political Instability and Economic Growth in Argentina (1896-2000)

Nauro F. Campos

Menelaos G. Karanasos

Bin Tan

October 2008 


\title{
Two to Tangle: Financial Development, Political Instability and Economic Growth in Argentina (1896-2000)
}

\author{
Nauro F. Campos \\ Brunel University, \\ CEPR and IZA \\ Menelaos G. Karanasos \\ Brunel University \\ Bin Tan \\ Brunel University
}

Discussion Paper No. 3752

October 2008

\author{
IZA \\ P.O. Box 7240 \\ 53072 Bonn \\ Germany \\ Phone: +49-228-3894-0 \\ Fax: +49-228-3894-180 \\ E-mail: iza@iza.org
}

Any opinions expressed here are those of the author(s) and not those of IZA. Research published in this series may include views on policy, but the institute itself takes no institutional policy positions.

The Institute for the Study of Labor (IZA) in Bonn is a local and virtual international research center and a place of communication between science, politics and business. IZA is an independent nonprofit organization supported by Deutsche Post World Net. The center is associated with the University of Bonn and offers a stimulating research environment through its international network, workshops and conferences, data service, project support, research visits and doctoral program. IZA engages in (i) original and internationally competitive research in all fields of labor economics, (ii) development of policy concepts, and (iii) dissemination of research results and concepts to the interested public.

IZA Discussion Papers often represent preliminary work and are circulated to encourage discussion. Citation of such a paper should account for its provisional character. A revised version may be available directly from the author. 


\section{ABSTRACT \\ Two to Tangle: Financial Development, Political Instability and Economic Growth in Argentina (1896-2000)}

This paper investigates the effects of financial development and political instability on economic growth in a power-ARCH framework with data for Argentina from 1896 to 2000. Our findings suggest that (i) informal or unanticipated political instability (e.g., guerrilla warfare) has a direct negative impact on growth; (ii) formal or anticipated instability (e.g., cabinet changes) has an indirect (through volatility) impact on growth; (iii) the effect of financial development is positive and, surprisingly, not via volatility; (iv) the informal instability effects are much larger in the short- than in the long-run; and (v) the impact of financial development on economic growth is negative in the short- but positive in the long-run.

JEL Classification: $\quad$ C14, O40, E23, D72

Keywords: economic growth, financial development, volatility, political instability, power-ARCH

Corresponding author:

Nauro F. Campos

Department of Economics and Finance

Brunel University (West London)

Uxbridge UB8 3PH

United Kingdom

E-mail: nauro.campos@brunel.ac.uk

\footnotetext{
"We thank Luis Catao, Alec Chrystal, Christian Conrad, Stijn Claessens, Bertrand Candelon, Richard Easterlin, John Hunter, Marika Karanassou, Michail Karoglou, Ayhan Kose, Christopher Martin, Andrew Powell, Marianne Schulze-Ghattas, Mariano Tommasi and seminar participants at the Centre for Financial and Management Studies at the University of London, University of Macedonia, ETH Zurich, Cass Business School ( $2^{\text {nd }}$ EMG Conference), $40^{\text {th }}$ Annual Conference of the Money, Macro and Finance Research Group (London) and Inter-American Development Bank for valuable comments on previous versions. We also would like to thank Lee Alston and Andres Gallo for kindly sharing their data with us. The usual disclaimer applies.
} 


\section{INTRODUCTION}

Instability and economic performance are often inversely related. Financial crises are associated with growth decelerations and contractions, while political protest tends to disrupt productive activities thereby affecting economic growth negatively. Such amplified uncertainties, driven either by economic or political events, have deleterious consequences in terms of economic performance, especially in the short-run. In the long-run, however, financial development and political instability may instead have positive effects on growth. For example, the supply of credit to the private sector and transitions from autocracy to democracy are often considered key determinants of long-run growth across countries. The aim of this paper is to put forward a comprehensive characterization of these relationships. More specifically, this paper tries to answer the following questions. What is the relation between, on the one hand, financial development and political instability and, on the other, economic growth and its volatility? Are the effects of these economic and political uncertainties fundamentally different? Does the sign and intensity of such effects vary over time and do they vary with respect to short- versus long-run considerations? Is there a dynamic asymmetry in the impact of financial development (that is, is it negative in the short- and positive in the long-run)?

This paper tries to tackle these questions using a power-ARCH (PARCH) framework and annual time series data for Argentina covering the period from 1896 to 2000. There are three related lines of research we should highlight and to which this paper tries to contribute, namely the scholarship on finance and growth, the economic literature on political instability, and the economic history work on the Argentine puzzle.

In terms of the finance-growth nexus, this paper tries to contribute by offering novel econometric evidence based on historical data. Doing so, allow us to investigate inter alia whether the impact of financial development on growth occurs directly or through growth 
volatility. ${ }^{1}$ Levine (2005) argues that the prevailing consensus favors a positive, lasting, significant and causal effect from financial development to economic growth and that such effects are predictably stronger from measures of financial efficiency (for instance, the share in GDP of credit to the private sector) than from measures of financial depth (such as M3 over GDP). Thereby using a range of measures of financial development we throw light on the impacts of these different measures over a much longer period of time than normally considered in the current literature. In addition to whether finance affects growth directly or through growth volatility, another important issue we tackle is that identified by Kaminsky and Schmukler (2003), Tornell et al. (2004) and Loayza and Ranciere (2006). Although the development of the financial system is robustly associated with economic growth across countries, it is also often found to be the main predictor of financial crises. That is, while the long-run effect of finance on growth is positive, in the short-run it is negative. However, cross-country heterogeneity, in general, and business cycles synchronization issues, in particular, may play an undesirably large role in generating this result. Because in this paper we use data for only one country and find supporting evidence for this asymmetric dynamic effect, one possible contribution of our paper is to help dispel such concerns about this important result. ${ }^{2}$

As for political instability, this paper tries to contribute in three ways: by bridging literatures, by exploring puzzles and by further clarifying the nature of the instability effects. Let us explain each of these in turn. One intended contribution is to try to bridge the literature on the macroeconomics of instability (based on cross-sectional and short-panels) with that on the relationship between growth and its volatility, which is mostly time-series

\footnotetext{
1 Levine (2005) surveys the finance and growth literature. On finance and volatility, see Bekaert et al. (2006) and Prasad et al. (2004.)

2 One important issue, which is beyond the scope of this paper, is regarding the causes of financial development, in particular, the legal origins versus political institutions debate (see Haber and Perotti, 2007.)
} 
based. ${ }^{3}$ The latter tends to downplay the potential dependence between the two variables by assuming a linear relationship, the so called Bollerslev GARCH specification.

Secondly, we try to shed light on important puzzles such as the one regarding the duration of the political instability effects. While the conventional wisdom is that these effects are severe in the long-run, Campos and Nugent (2002) ${ }^{4}$ and Murdoch and Sandler (2004) argue that they are stronger in the short- than in the long-run. Another puzzle we address is on the sign of the growth-volatility link: while Grier and Tullock (1989) argue that larger standard deviations of growth rates are associated with larger mean growth rates, Ramey and Ramey (1995) show that output growth rates are adversely affected by their volatility.

Thirdly, we explore the hypothesis that different types of political instability may have different effects on economic growth. We do this by further developing the distinction between formal and informal instability introduced in Campos and Karanasos (2008). The distinction is based on whether or not different forms of instability originate from within the political system: anti-government demonstrations and guerrilla warfare are thus informal political instability, while constitutional reforms and government purges are classified as formal instability. In addition to the obvious policy implications this taxonomy supports (in a literature in which policy implications are scarce), this distinction allows us to investigate questions that have not been investigated so far, such as whether or not the effect of informal instability is more severe in the short-run and whether or not the main effect of formal instability occurs through growth volatility. ${ }^{5}$

\footnotetext{
3 Durlauf et al. (2005) survey the former, and Grier et al. (2004), Fountas and Karanasos (2006) and Fountas et al. (2007) review the latter. One paper that tries to link these literatures, and is close to ours in this sense, is Asteriou and Price (2001), which present time series (quarterly) data evidence for the UK since 1960.

4 Campos and Nugent (2002) argue that the long-run negative effect of political instability on growth vanishes without the African countries and/or once institutions are taken into account.

5 Among our hypotheses is that the answer to these two questions is yes. We provide further justification and econometric support below.
} 
Last, but not least, our third intended contribution is to put forward novel econometric evidence on the Argentine puzzle (della Paolera and Taylor, 2003). Since the Industrial Revolution, Argentina is the only country that was developed in 1900 and developing in 2000 (see Figure 1). Although a large literature associates this decline to financial and political factors, we are unaware of studies that build this argument quantitatively, so we think ours may be a contribution to this economic history literature. ${ }^{6}$

Anticipating our main findings, we note the following in relation to the questions raised at the outset. The relationship between, on the one hand, financial development and political instability and economic growth, on the other, is not as straightforward as one may think at first. We find that it crucially depends on the type of political instability and of financial development, as well as short- versus long-run considerations. The short-run effect on economic growth of both informal instability and financial development is negative and direct and these results are robust to accounting for structural breaks, the latter being obviously important in light of the long time span we cover in this study. Yet, while the long-run influence of finance is positive, that of informal instability remains negative. We also find that the impact of formal instability, on the other hand, is indirect and operates through growth volatility. These provide the basis for our assessment that these economic and political effects are fundamentally different. Moreover, these results seem to suggest that the "severity" of the political instability effects "surpasses" that of financial development. After all, while the short- and long-run finance effects work in opposite directions, the effects of political instability are both negative and, equally importantly, operate through different channels. We believe the importance of these findings is also in

6 Campos et al. (2008) present econometric evidence supporting the view that political instability and financial development are more important factors to understand Argentinean growth over the last 100 years or so than the other factors highlighted in this literature (such as international financial market conditions, public deficits, and inflation.) 
terms of the policy lessons they generate. The vast existing literature has said little in this respect as it focused on informal instability which is, by construction, not influenced by government policy. In this paper, we show that formal political instability is detrimental to growth via the volatility channel and, together with informal instability, may have played a truly substantial role in the demise of the Argentinean economy since the 1890s.

The paper is organized as follows. Section 2 sets the historical context for the paper by showing how political instability and financial development contributed to the decline of Argentina from a position of a rich or developed country in year 1900 to that of a middle-income or developing country in year 2000. Section 3 describes our data. Section 4 details our econometric methodology. Section 5 contains our baseline econometric results as well as our two main sensitivity tests: on short- and long-run considerations and structural breaks. Section 6 concludes and suggests directions for future research.

\section{FINANCE AND INSTABILITY IN ARGENTINA}

Among economic historians, there is little disagreement that the period from 1875 to the eve of World War I is the Belle Époque of recent Argentinean history (Taylor, 1992; Sanz-Villarroya, 2007). There is also little disagreement among scholars that the Argentina's uniqueness is because no other country climbed down so dramatically from the selected group of developed countries. The major disagreement among economic historians to this day is not whether but actually when the unchecked decline started. Some argue that it started with the 1930 crisis (e.g., Diaz-Alejandro 1985), others argue for an earlier turning point (Taylor argues for 1913), while Sanz-Villarroya (2005) calculates that the first important structural break for Argentina happens in 1899.7

\footnotetext{
7 Below we present and discuss our Bai-Perron estimates of the date of structural breaks in Argentinean growth. We find (and adjust our estimates accordingly below) evidence for two structural breaks: 1922 and 1964.
} 
Irrespective of exactly when the decline started, it is also clear that its existence was not undisputed until the immediate post II World War. In 1947 Argentina was still ranked 10th country in the world in terms of per capita income (Alston and Gallo, 2007, p. 6). della Paolera and Taylor (2003) note that "by 1900 Argentina's income per capita had risen from about 67 per cent of developed country-levels in 1870, to 90 percent in 1900, and 100 per cent in 1913. Whatever its exact status in 1913, for all practical purposes Argentina was an advanced country" (2003, p. 5). They also calculate that since then the ratio of Argentina's income to OECD income fell to 84 percent in 1950, and then to 43 percent in 1987 . This ratio rebounds in the 1990 s but again reverts with the 2001 crisis. $^{8}$ It must not go unnoticed that in a recent book on the Great Depressions of the XXth Century (Kehoe and Prescott, 2007), Argentina is the only country that has two chapters (out of 16) entirely and solely dedicated to its economy.

It is not surprisingly, therefore, that there is a vast literature on the Argentine puzzle, providing alternative explanations for the long-run relative decline of the Argentinean economy. Finance has received a great deal of attention too in terms of potential role in explaining the decline (della Paolera and Taylor, 1998). Fort instance, Prados de la Escosura and Sanz-Villarroya (2006) argue that contract intensive money is the key in explaining the Argentine puzzle. Taylor (2003) associates the decline to low savings rates (the high dependency rate linked to the immigration policy). This may also combine well with Solberg view to highlight the issue of (restricted) access to finance as a way of perpetuating the high inequality levels.

Although a large literature associates the long-run relative decline of the

8 Growth was negative from 1999 onwards culminating with around $-10 \%$ in year 2002 . The 2001 crisis entailed a default on large part of the external debt, devaluation, inflation, and the freezing of bank accounts (the corralito.) Riots, looting and anti-government demonstrations followed. See Kehoe (2003) for a discussion. 
Argentinean economy with political factors, ${ }^{9}$ we are unaware of studies that try to quantitatively evaluate this association. For instance, Acemoglu and Robinson (2006) observe that: "The political history of Argentina reveals an extraordinary pattern where democracy was created in 1912, undermined in 1930, re-created in 1946, undermined in 1955, fully re-created in 1973, undermined in 1976, and finally reestablished in 1983" (2006, p. 7). In a recent paper, Alston and Gallo (2007) identify the onset of widespread electoral fraud in the 1930s as a turning point for the erosion of the rule of law and one main reason for the Argentinean decline.

In what follows, we take these considerations on board in trying to provide a comprehensive quantitative account of the relative importance of two of the main reasons often identified with the Argentinean debacle, namely political instability and financial development.

\section{DATA}

The data set we put together for this paper comprises various measures of political instability, financial development and economic growth. Our main data source is the Cross National Time Series Data set (Banks 2005) which contains historical series on income per capita and various dimensions of instability. ${ }^{10}$ This is a commercial database that has been extensively used in the scholarship on growth and political instability (Durlauf et al., 2005.) Data are available yearly for Argentina from 1896 until 2000, for various instability series, excluding the two World War years (that is, 1914 to 1918 and 1939 to 1945).

In order to facilitate the interpretation of our results we use a taxonomy of political

\footnotetext{
9 See also della Paolera and Taylor (2003) and references therein.

10 We have obtained GDP growth and level figures from various other sources (as well as industrial output series) in order to assess the sensitivity of the results in this regard and the initial results (not reported) show that different measures of the rate of economic growth do not affect our results below.
} 
instabilities based on the distinction between formal and informal (that is, whether or not it originates from within the political system). ${ }^{11}$ Our informal political instability variables are as follows: anti-government demonstrations (peaceful public gatherings of at least 100 people), assassinations (defined as politically motivated murder or attempted murder of a high government official or politician), guerrilla warfare (armed activity, sabotage, or bombings by independent bands of citizens and aimed at regime overthrow), strikes (a general strike of 1,000 or more workers involving more multiple employers and aimed at government policies), and revolutions (illegal or forced change in the top governmental elite, attempts at, or successful or unsuccessful armed rebellion). These series are available since 1919. Our informal political instability variables are as follows: the number of cabinet changes, the size of the cabinet, the number of constitutional changes, government crises, the number of legislative elections, and purges (which measure any systematic elimination by jailing or execution of political opposition within the ranks of the regime or the opposition. $)^{12}$

We use various measures of financial development. One is the ratio of M3 to GDP, from Alston and Gallo (2007). The main reason for considering this measure is that it has been used extensively in the finance-growth literature (King and Levine, 1993; Levine, 2005). One well-known drawback of this measure, however, is that the ratio of M3 to GDP reflects financial depth or the relative size of the financial system. It does not necessarily reflect how efficient the financial system actually is. We also use a narrower version of this variable (M1 over GDP) to check for the robustness of our results (source of the data for this measure is Bordo et al., 2001). Our other two measures of financial development try to

11 Our political instability variables enter one by one in the econometric framework we use, so our results are not affected by the taxonomy and as such it is used simply to facilitate the interpretation.

12 In our view, among all informal instability variables, "purges" is the closest to what we call formal instability, while "revolutions" is the one we think is closer to our formal instability variables (among informal instability.) 
capture the efficiency of the financial sector, not its relative size. The source for both is Mitchell (2003). The first is the bank deposits by the private sector over GDP (private deposits), which we believe is a good proxy for the share of credit to the private sector over GDP. Our second measure from Mitchell (2003) is the total deposits in savings banks over GDP. Given its more restrictive nature and the fact that the exact definition of savings bank contains a fluid legal element, we use this measure mostly for robustness check thereby attaching greater weight to private deposits. ${ }^{13}$

\section{METHODOLOGY}

The PARCH model was introduced by Ding, Granger and Engle (1993) and quickly gained currency in the finance literature. ${ }^{14}$ Let growth $\left(y_{t}\right)$ follow a white noise process augmented by (i) a risk premium defined in terms of volatility $\left(h_{t}\right)$, and (ii) either a political instability or a financial development variable $\left(x_{i t}\right)$ :

$$
y_{t}=c+k h_{t}+\lambda x_{i t}+\varepsilon_{t},
$$

with

$$
\varepsilon_{t}=e_{t} h_{t}^{\frac{1}{2}}
$$

where $\left\{e_{t}\right\}$ are independently and identically distributed (i.i.d) random variables with $\mathrm{E}\left(e_{t}\right)=\mathrm{E}\left(e_{t^{2}}-1\right)=0$, while $h_{t}$ is positive with probability one and is a measurable function of the sigma-algebra $\sum_{t-1}$, which is generated by $\left\{y_{t-1}, y_{t-2}, \ldots\right\}$.

In other words, $h_{t}$ denotes the conditional variance of growth. In particular, $h_{t}$ is specified as an asymmetric $\operatorname{PARCH}(1,1)$ process with lagged growth included in the

\footnotetext{
13 Because the original financial development variables are I(1), we use them all in first differences.

14 See, for example, Karanasos and Kim (2006). Karanasos and Schurer $(2005,2008)$ use this process to model output growth and inflation respectively.
} 
variance equation:

$$
h_{t}^{\frac{\delta}{2}}=\omega+\alpha h_{t-1}^{\frac{\delta}{2}} f\left(e_{t-1}\right)+\beta h_{t-1}^{\frac{\delta}{2}}+\gamma_{l} y_{t-l}+\phi x_{i t},
$$

with

$$
f\left(e_{t-1}\right)=\left[\left|e_{t-1}\right|-\varsigma e_{t-1}\right]^{\delta}
$$

where $\delta$ (with $\delta>0$ ) is the heteroscedasticity parameter, $\alpha$ and $\beta$ are the ARCH and GARCH coefficients respectively, $\varsigma$ with $|\varsigma|<1$ is the leverage term and $\gamma_{l}$ is the level term for the $l$ th lag of growth. ${ }^{15}$ In order to distinguish the general PARCH model from a version in which $\delta$ is fixed (but not necessarily equal to two) we refer to the latter as (P)ARCH.

The PARCH model increases the flexibility of the conditional variance specification by allowing the data to determine the power of growth for which the predictable structure in the volatility pattern is the strongest. This feature in the volatility process has important implications for the relationship between political instability, finance, and growth and its volatility. There is no strong reason for assuming that the conditional variance is a linear function of lagged squared errors. The common use of a squared term in this role is most likely to be a reflection of the normality assumption traditionally invoked. However, if we accept that growth data are very likely to have a non-normal error distribution, then the superiority of a squared term is unwarranted and other power transformations may be more appropriate.

The PARCH model may also be viewed as a standard GARCH model for observations that have been changed by a sign-preserving power transformation implied by a (modified) PARCH parameterization. He and Teräsvirta (1999) emphasize that if the standard

\footnotetext{
15 The model imposes a Box-Cox power transformation of the conditional standard deviation process and the asymmetric absolute residuals.
} 
Bollerslev type of model is augmented by the heteroscedasticity parameter (the power term), the estimates of the $\mathrm{ARCH}$ and GARCH coefficients almost certainly change. ${ }^{16}$

Moreover, by squaring the growth rates one effectively imposes a structure on the data which may potentially yield sub-optimal modeling and forecasting performance relative to other power terms. One way to assess the severity of this assumption is to investigate the temporal properties of the power transformed absolute growth $\left|y_{t}\right|^{d}$. First, we examine the sample autocorrelations of the power transformed absolute growth $\left|y_{t}\right|^{d}$ for various positive values of $d$. Figure 4 shows the autocorrelogram of $\left|y_{t}\right|^{d}$ from lag 1 to 20 for a range of $d$ values. The horizontal lines show the $\pm 1.96 / \sqrt{T}$ confidence interval (CI) for the estimated sample autocorrelations if the process $y_{t}$ is i.i.d. In this particular case, CI $= \pm 1.96 / \sqrt{T}= \pm 0.2032$.

The sample autocorrelations for $\left|y_{t}\right|^{0.8}$ are greater than the sample autocorrelations of $\left|y_{t}\right|^{d}$ for $d=0.9,1,1.5,2$ and 2.5 at every lag. Or to put it differently, the most important conclusion from the autocorrelogram is that $\left|y_{t}\right|^{d}$ has the largest autocorrelation when $d=0.8$. Furthermore, the power transformations of absolute growth when $d$ is 0.8 have significant positive autocorrelations at least up to lag 10. Moreover, note that at all lags, $\left|y_{t}\right|^{d}$ has the lowest autocorrelation when $d=2$. This result appears to argue against Bollerslev specification.

Above all, the statistical significance of the in-mean effect is highly dependent on the choice of the value of the heteroscedasticity parameter. The effect might become insignificant if the power term surpasses a specific value. This suggests that if one assumes

\footnotetext{
16 Karanasos and Schurer (2008) find that the relationship between the variable and its conditional variance is sensitive to changes in the values of the heteroscedasticity parameter. Put differently, the estimated values of
} 
a priori a linear relationship between a variable and its uncertainty, the so-called Bollerslev specification, a significant link between the two might not be detected. Interestingly, Karanasos and Schurer (2008) find that for inflation this value coincides with the one chosen by the information criteria and the one for which the sample autocorrelation of the power-transformed series is maximal.

\section{RESULTS}

We proceed with the estimation of the $\operatorname{PARCH}(1,1)$ model in equations (1) and (2) in order to take into account the serial correlation observed in the levels and power transformations of our time series data. The Tables below report the estimated parameters of interest for the period 1896-2000. These were obtained by quasi-maximum likelihood estimation (QMLE) as implemented in EVIEWS. The best fitting specification is chosen according to the Likelihood Ratio (LR) results and the minimum value of the Information Criteria (IC) (not reported). Once heteroscedasticity in the conditional mean has been accounted for, our specifications appear to capture the serial correlation in the growth series. ${ }^{17}$

In order to study the direct effects of political instability and financial development we specify model 1 with $\phi=\gamma_{l}=0$ in equation 2 , while model 2 with $\lambda=0$ in equation 1 allows us to investigate their indirect impacts on growth. ${ }^{18}$ In all cases the estimates for the in-mean parameter $(k)$ are statistically significant and positive. The estimated ARCH and GARCH parameters ( $\alpha$ and $\beta$ ) are highly significant in all cases but one.

For model $1\left(\phi=\gamma_{l}=0\right)$, when the informal political stability variables are used, the

the in-mean and the level effects are fragile to changes in the power term.

17 For all cases, we find that the leverage term is insignificant, so we re-estimate excluding this parameter.

18 With a limited number of observations the non-linear structure should not be overextended as this imposes excessive requirements on the data. Therefore we estimate the direct (model 1) and the indirect (model 2) effects separately. 
estimated power term coefficient $\delta$ ranges from 0.8 (revolutions) to 1.0 (anti-government demonstrations). ${ }^{19}$ The corresponding value for all but one specification with formal instability variables is 0.8 (last column of Table 1). For model 2 (with $\lambda=0$ ), with the informal instability variables Akaike IC (AIC) selects (P)ARCH models with $\delta$ equal to 0.9 (anti-government demos, guerrilla warfare and strikes) or to 0.8 (assassinations and revolutions). ${ }^{20}$ For three out of the six formal variables the estimated value of $\delta$ is 1 (last column of Table 2). Finally, for both models 1 and 2, when the financial development variables are used, in all but one cases the IC chooses a (P)ARCH specification with estimated power term 0.8 .

From the results for Model 1 reported in Table 1, the parameters $\lambda$ for assassinations, guerrilla warfare and strikes (three measures of informal political instability) reveal their direct, negative and statistically significant impact on economic growth. Note that none of the corresponding effects for the formal instability variables are statistically significant (Panel B). Importantly, we find the impact of financial development on economic growth to be positive and statistically significant, irrespective of the variable we use to proxy for it (the least significant coefficient being that on M3/GDP.)

The results in Table 1 are particularly interesting mainly for two reasons. One is that they provide evidence strongly suggesting that the type of political instability matters vis-à-vis economic growth: informal instability has a direct and negative effect, while formal instability clearly does not. Second, they show that financial development has a positive and direct effect on growth, with M3 over GDP (a measure of the size of the financial sector, not of its efficiency) arguably being the weakest effect.

\footnotetext{
19 With a limited number of time-series observations it is not feasible to estimate with sufficient accuracy the power term.

20 In the expressions for the conditional variances reported in Table 2, various lags of growth (from 1 to 12 ) were considered with the best model $(l=6)$ chosen on the basis of the minimum value of the AIC.
} 
Examining the results for Model 2 (reported in Table 2) and focusing our attention on the $\phi$ and $k$ parameters, ${ }^{21}$ we can now see that the formal political instability variables have strong indirect (through volatility) negative effects on growth. This result obtains for cabinet changes and size, and constitutional changes. That is, these three variables affect volatility negatively $(\phi<0)$ and, since $k>0$, they affect growth negatively as well. Interestingly, none of the financial development and informal instability measures reveals such indirect effects (instead, as discussed above, they exhibit a direct impact on growth). These results reinforce the notion that the type of political instability matters vis-à-vis economic growth: while informal may have a direct impact, the effect of formal political instability operates indirectly, via growth volatility.

\subsection{SHORT- AND LONG-RUN ISSUES}

In this section we investigate how short- and long-run considerations help us refine our baseline results. In order to estimate short- and long- run relationships we employ the following error correction (P)ARCH form

$$
\Delta y_{t}=\theta_{l} \Delta x_{i, t-l}+\varphi\left(y_{t-1}-c-\lambda x_{i, t-1}\right)+u_{t}
$$

where $\theta_{l}$ and $\lambda$ captures the short and long-run effects respectively, and $\varphi$ is the speed of adjustment to the long-run relationship. ${ }^{22}$ This is accomplished by embedding a long-run growth regression into an ARDL model..$^{23}$ In other words, the term in parenthesis contains the long-run growth regression, which acts as a forcing equilibrium condition

\footnotetext{
21 Note that, for all cases in model 2, there is evidence of a positive bidirectional feedback between growth and its volatility. The existing empirical literature focuses mainly on the effect of volatility on growth, see Fountas et al. (2006) and Fountas and Karanasos (2007).

22 As pointed out by Loayaza and Rancière (2006) the requirements for the validity of this methodology are that: i) there exists a long-run relationship between the variables of interest and, ii) the dynamic specification of the model is sufficiently augmented so that the regressors are strictly exogenous and the resulting residual is serially uncorrelated.

23 For details on the "ARDL approach," see Pesaran (1997) and Pesaran and Shin (1999).
} 


$$
y_{t}=c+\lambda x_{i t}+\varepsilon_{t}
$$

where $\varepsilon_{t}$ is $I(0) .^{24}$ The lag of the first/second difference of the political instability/financial development variable $\left(\Delta x_{i, t-l}\right)$ characterizes the short-run effect. The condition for the existence of a long-run relationship (dynamic stability) requires that the coefficient on the error-correction term be negative and not lower than -2 (that is, $-2<\varphi<0$ ). We also take into account the power $\mathrm{ARCH}$ effects by specifying the error term $u_{t}$ as follows

$$
u_{t}=e_{t} h_{t}^{\frac{1}{2}}
$$

where

$$
h_{t}^{\frac{\delta}{2}}=\omega+\alpha\left|u_{t-1}\right|^{\delta}+\beta h_{t-1}^{\frac{\delta}{2}} \text {. }
$$

Table 3 presents the results on the estimation of short and long-run parameters linking informal instability or financial development with growth. In all cases, the estimated coefficient on the error correction term $(\varphi)$ lies within the dynamically stable range $(-2,0)$. More precisely, the estimates of $\varphi$ for informal instability and financial development lie within the range -0.71 to -0.50 and -0.85 to -0.44 , respectively.

Regarding the short and long-run effect estimates, $\theta_{l}$ and $\lambda$, we focus our analysis first on those obtained from the informal instability variables. In all cases the estimates of the short-run coefficients are highly significant and negative and their absolute values are higher than the corresponding values for the long-run coefficients (for anti-government

\footnotetext{
$24 \varepsilon_{t}$ follows a (P)ARCH process given by equations (2)-(3) with $\gamma_{l}=\phi=\varsigma=0$.
} 
demonstrations, the long-run effect is not significantly different from zero). This provides supporting evidence for the notion that the duration of the political instability effect does indeed matter and, for informal instability, such effects tend to be considerably stronger in the short- than in the long-run as previously noted by Campos and Nugent (2002) and Murdoch and Sandler (2004). The unexpected result is for revolutions: we found that the long-run effect on growth is positive. One possible explanation is that of escalation: political instability comes in cycles in which the level of political violence accelerates, with maxima coinciding with revolutions. Because revolutions reflect illegal or forced change in the top government elite (as well as successful or unsuccessful armed rebellions), their occurrence may be the culmination of a cycle of political violence, thus marking the beginning of a period of relatively low levels of political instability (and higher or more stable growth rates.) Another piece of evidence we can offer in support of this conjecture is that the revolutions series peaks around the date of the second structural break we identify in the GDP growth series (we noted above, and will discuss this issue in full in the next section below, that we find two breaks in the growth series, the first in year 1922 and the second in year 1964.)

Next we discuss the results regarding the financial development variables. In the long-run, we find that financial development affects growth positively. This result is very much in line with the large empirical literature reviewed by Levine (2005) and it is interesting we can reproduce it with our rather different methodology. Maybe more interestingly, the short-run coefficients tell a very differently story: we find that the short-run impact of financial development on growth is negative and significant. Thus our results square well with recent findings by Loayaza and Rancière (2006), among others, in that the sign of the relationship between economic growth and financial development depends on whether the movements are temporary or permanent (the effect being negative in the former and positive in the latter.) Finally, it is noteworthy that our results are robust 
to various measures of financial development and also that the stronger long-run effects we obtain are for our measures of financial efficiency rather than for our measures of the size of the financial sector (according to Levine, 2005, this is also in line with the recent evidence).

\subsection{STRUCTURAL BREAKS}

In this section we subject our baseline results to an important robustness test. That is, we asses whether taking structural breaks into account affects our main results. We find that, overall, it does not.

We use the methodology developed by Bai and Perron (2003) to examine whether there are any structural breaks in growth, its volatility, the various political instability series and the first differences of the four financial development variables. Bai and Perron (2003) address the problem of testing for multiple structural changes under very general conditions on the data and the errors. In addition to testing for the existence of breaks, these statistics identify the number and location of multiple breaks. ${ }^{25}$

In the case of the economic growth series (and, interestingly, also for growth volatility) the Bai-Perron methodology supports two structural break points. ${ }^{26}$ The first occurs for year 1922 and the second for year 1964. For our political instability variables, we find no structural breaks for the assassinations, guerilla warfare, cabinet and constitutional changes series, ${ }^{27}$ and we also find no breaks in the four financial development variables.

However, our Bai-Perron results support that general strikes and government crises have one common structural break, which is dated for year 1955. This is a result of great

\footnotetext{
25 Details are available from the authors upon request.

26 As a measure of volatility, we use the power transformed absolute growth.

27 Our data shows no guerilla warfare before 1948 and after 1977.
} 
importance: 1955 is the year of the military coup in which President Juan Domingo Perón was overthrown by the military thus concluding a defining chapter in Argentine history. Breaks in the revolutions and purges series are detected for about the same political period, more specifically for year $1951 .{ }^{28}$ Further, we also find one structural break in cabinet size and legislative elections (they are dated 1946 and 1949, respectively) while in anti-government demonstrations we find two breaks dated 1954 and 1972. ${ }^{29}$

In what follows, we incorporate dummy variables in the equations (1), (2), thus taking into account breaks in the political instability variables and in the volatility of growth. First, we introduce the following notation. $D_{1 t}, D_{2 t}$ are (intercept) dummies defined as $D_{1 t}, D_{2 t}=1$ in the periods $1922-2000$ and 1964-2000, respectively, and $D_{1 t}, D_{2 t}=0$ otherwise. Similarly, $D_{i t}$ is a (slope) dummy indicating the period which starts from the year of the break in the political instability variable $\left(x_{i t}\right)$. For example for strikes and government crises $D_{i t}=1$ in the period from 1955 to 2000 whereas for cabinet size $D_{i t}=1$ during the period from 1946 until the end of the sample.

The augmented model is given by

$$
y_{t}=c+k h_{t}+\lambda x_{i t}+\lambda_{1} D_{i t} x_{i t}+\varepsilon_{t},
$$

and

$$
h_{t}^{\frac{\delta}{2}}=\omega+\omega_{1} D_{1 t}+\omega_{2} D_{2 t}+\alpha h_{t-1}^{\frac{\delta}{2}} f\left(e_{t-1}\right)+\beta h_{t-1}^{\frac{\delta}{2}}+\gamma_{l} y_{t-l}+\phi x_{i t}+\phi_{1} D_{i t} x_{i t}
$$

\footnotetext{
28 In purges there is a second break dated 1978 but since after that year there were no purges we do not need to use a dummy variable.

29 With arguably one exception (anti-government demonstrations in 1972, which were motivated by demands for the return of Perón from exile), all the structural breaks in our political instability series occur during Perón governments. Perón was elected president three times. His first term is from 1946 to 1952 . He is re-elected in 1951, his second term starts in 1952 and ends abruptly in 1955. His third term is between 1973 (allowed to return from Spain after 18-year exile) and 1974 (suffers fatal heart attack.) Although marked by severe economic problems, the second term (1951 to 1955) is more often remembered by the political instability (the various terrorist attacks being a sad prelude to the so-called "Dirty War" of 1970s.)
} 
Recall that the coefficients $\lambda$ and $\varphi$ capture the impacts of the political instability variable on growth and its volatility respectively. Similarly, $\lambda_{1}$ and $\varphi_{1}$ correspond to the two effects from the year of the break onwards. Thus the two effects are captured by $\lambda$ and $\varphi$ in the period up to the year of the structural break, and by $\lambda+\lambda_{1}$ and $\varphi+\varphi_{1}$ during the period from the year of the break until the end of the sample. As in section 4 in order to study the direct effects of political instability and financial development we specify model 1 with $\varphi=\varphi_{1}=0$, while model 2 with $\lambda=\lambda_{1}=0$ allows us to investigate their indirect impacts on growth.

We also incorporate intercept dummies and level effects in the conditional variance equation (5), as follows

$$
h_{t}^{\frac{\delta}{2}}=\omega+\omega_{1} D_{1 t}+\omega_{2} D_{2 t}+\alpha\left|u_{t-1}\right|^{\delta}+\beta h_{t-1}^{\frac{\delta}{2}}+\gamma_{l} y_{t-l}
$$

Overall, we find our results to be quite robust to the inclusion of the structural break dummies (see Tables 4-6). ${ }^{30}$ That is, (i) informal instability have a direct negative effect on growth, while formal instability have an indirect (through volatility) negative impact on growth, (ii) financial development affects growth positively in the long-run but negatively in the short-run, (iii) the effects of the informal instability are significantly stronger in the short- than in the long-run.

It is also noteworthy that before 1951, growth is independent of changes in purges, whereas after 1951 a negative, causal relationship began to exist (meaning that purges behaves similarly to our informal instability variables). In addition, the impact of

\footnotetext{
30 The results (not reported) are also robust to the inclusion of intercept dummies in the mean equation for growth as well.
} 
revolutions on growth becomes negative after 1951. Note also that the causal negative effect of strikes reflects the period 1955-2000 (see Panels A and B of Table 4), which is not surprising given the intricate relationship between the governments of Peron and organized labor. Interestingly, the negative causal effects from legislative elections and government crises to growth volatility, become stronger after 1949 and 1955 respectively (see Panel B of Table 5.) Finally, note that when we take into account breaks and level effects in the volatility of growth, the long-run effects of anti-government demonstrations, assassinations and revolutions disappear (see Panel A of Table 6) thereby reinforcing our finding that the effects of informal political instability are more severe in the short- than in the long-run. Moreover, the coefficient of M3 over GDP also becomes insignificant, while the same does not happen to the measures that go beyond the size of the financial sector.

\section{CONCLUSIONS}

In a power-ARCH framework using data for Argentina from approximately 1890 to 2000 this paper found that: (a) informal political instability (assassinations, guerilla warfare, strikes, etc.) have a direct negative effect on economic growth, while formal instability (e.g., cabinet changes and size, and constitutional changes) have an indirect impact on growth (through its volatility); (b) financial development affects economic growth positively; (c) the informal instability effects are substantially larger in the short- than in the long-run; and (d) the financial development effects are negative in the short- but positive in the long-run.

These findings are interesting in themselves but they also matter because they raise a number of new questions that we believe may be useful in motivating future research. Here we highlight two related suggestions: one on the role of finance and one on methodology. Regarding the role of finance in the process of economic development, our finding reinforces a large body of previous research in that we also show a strong, positive 
impact of financial development on growth in the long-run. However, the negative effects of political instability on growth might outweigh the positive influence of financial development. We find that different forms of political instability affect growth through different channels over different time windows, making up for a strong and rather resilient effect that seem really too powerful vis-à-vis the benefits brought to the table by financial development. We can not forget however that Argentina is unique: no other country in the world since the Industrial Revolution went from riches to rags. Put it differently, Argentina is an outlier and further research should replicate our analysis using the historical experience of other countries (ideally in a panel setting). That is, to study the relationship between political instability, financial development and economic growth in a panel of developing countries would strengthen what we know. However, it has to be taken into account that the data requirements are very heavy indeed, with most developing countries lacking historical data even on key figures, such as per capita GDP, going back to the beginning or middle of the XIXth century. This, of course, does not make this task less important. The second suggestion refers to a possible methodological improvement, namely the application of the bivariate PARCH model to the problem at hand (albeit the relatively small number of observations). The joint estimation of the political instability-financial development-growth system in a panel of countries would clearly represent progress and is something we feel future research should try to address. 


\section{REFERENCES}

Acemoglu, D. and J. Robinson, 2006. Economic Origins of Dictatorship and Democracy. Cambridge University Press, Boston.

Alston, L. and A.A. Gallo, 2007. Electoral Fraud, the Rise of Peron and Demise of Checks and Balances in Argentina. Mimeo, University of Colorado.

Asteriou, D. and S. Price, 2001. Political Instability and Economic Growth: UK Time Series Evidence. Scottish Journal of Political Economy 48, 383--399.

Bai, J. and P. Perron, 2003. Computation and Analysis of Multiple Structural Change Models. Journal of Applied Econometrics 18, 1-22.

Banks, A. 2005. Cross-National Time-Series Data Archive. Jerusalem: Databanks International. http://www.databanks.sitehosting.net.

Bekaert, G., Harvey, C.R. and C. Lundblad, 2006. Growth Volatility and Equity Market Liberalization. Journal of International Money and Finance 25, 2006, 370-403.

Bordo, M., Eichengreen, B., Klingebiel, D. and M. S. Martinez-Peria, 2001. Is the Crisis Problem Growing More Severe? Economic Policy 16(32), 51 - 82.

Campos, N. and M. Karanasos, 2008. Growth, Volatility and Instability: Non-Linear Time-Series Evidence for Argentina. Economics Letters 100(1): 135-37.

Campos, N., M. Karanasos and B. Tan, 2008. From Riches to Rags, and Back? Explaining the Growth Trajectory of Argentina since the 1890s, mimeo.

Campos, N. and J. Nugent, 2002. Who is Afraid of Political Instability? Journal of Development Economics 67, 157-172.

Diaz-Alejandro, C., 1985. Argentina, Australia and Brazil Before 1929. In Platt, D. C. M. and di Tella, Guido (Eds.), Argentina, Australia and Canada. Studies in Comparative Development 1870-1965. St. Martin's Press, New York.

Ding, Z., Granger, C.W.J. and R. Engle, 1993. A Long Memory Property of Stock Market Returns and a New Model. Journal of Empirical Finance 1, 83-106.

Durlauf, S., Johnson, P. and J. Temple, 2005. Growth Econometrics. In Aghion, P. and S. Durlauf (Eds.), Handbook of Economic Growth. North-Holland.

Fountas, S., M. Karanasos and J. Kim, 2006. Inflation Uncertainty, Output Growth Uncertainty and Macroeconomic Performance. Oxford Bulletin of Economics and Statistics 68, 319-343.

Fountas, S. and M. Karanasos, 2007. Inflation, Output Growth, and Nominal and Real Uncertainty: Empirical Evidence for the G7. Journal of International Money and Finance 26, 229-250. 
Grier, K., Henry, T., Olekalns, N. and K. Shields, 2004. The Asymmetric Effects of Uncertainty on Inflation and Output Growth. Journal of Applied Econometrics 19, 551-565.

Grier, K. and G. Tullock, 1989. An Empirical Analysis of Cross-National Economic Growth, 1951-1980. Journal of Monetary Economics 24, 48-69.

Haber, S. and E. Perotti 2007. The Political Economy of Finance, Stanford and Amsterdam, mimeo.

He, C. and T. Teräsvirta, 1999. Statistical Properties of the Asymmetric Power ARCH Model, in Engle, R. F. and H. White (eds), Cointegration, Causality and Forecasting. Festchrift in honour of Clive W. J. Granger. Oxford University Press, Oxford, 462-474.

Kaminsky, G. and S. Schmukler, Short-Run Pain, Long-run Gain: The Effects of Financial Liberalization, NBER Working Paper No. 9787, 2003.

Karanasos, M. and J. Kim, 2006. A Re-examination of the Asymmetric Power ARCH Model. Journal of Empirical Finance 13, 113-128.

Karanasos, M. and S. Schurer, 2005. Is the Reduction in Output Growth Related to the Increase in its Uncertainty? The case of Italy. WSEAS Transactions on Business and Economics 3, 116-122.

Karanasos, M. and S. Schurer, 2008. Is the Relationship Between Inflation and its Uncertainty Linear? German Economic Review, forthcoming.

Kehoe, T. J. 2003. What Can We Learn from the Current Crisis in Argentina? Scottish Journal of Political Economy 50, 609-33.

Kehoe, T.J. and E.C. Prescott (Eds.), 2007. Great Depressions of the Twentieth Century, Federal Reserve Bank of Minneapolis.

King, R.G. and R. Levine, 1993. Finance and Growth: Schumpeter Might be Right. Quarterly Journal of Economics 108, 717-737.

Levine, R. 2005. Finance and Growth: Theory and Evidence. In Aghion, P. and S. Durlauf (Eds.), Handbook of Economic Growth. Elsevier, Amsterdam.

Loayza, N. V. and R. Rancière, 2006. Financial Development, Financial Fragility and Growth. Journal of Money Credit and Banking, 38, 1051-1076.

Mitchell, B.R. 2003. International Historical Statistics: The Americas, 1750-2000. Palgrave MacMillan, London.

Murdoch, J. and T. Sandler, 2004. Civil Wars and Economic Growth: Spatial Dispersion. American Journal of Political Science 48, 138-151. 
della Paolera, G. and A. M. Taylor, 1998. Finance and Development in an Emerging Market: Argentina in the Interwar Period. In: Latin America and the World Economy since 1800, 139-169. Harvard University Press, Cambridge.

della Paolera, G. and A.M. Taylor, 2003 (eds). A New Economic History of Argentina. Cambridge University Press.

Pesaran, H. 1997. The Role of Econometric Theory in Modeling the Long Run. Economic Journal, 107, 178-191.

Pesaran, H. and Y. Shin, 1999. An Autoregressive Distributed Lag Modeling Approach to Cointegration. in Econometrics and Economic Theory in the 20th Century: The Ragnar Frisch Centennial Symposium, chap 4, pp. 371-413. Cambridge University Press.

Prados de la Escosura, L. and I. Sanz-Villarroya, 2006. Contract Enforcement and Argentina's Long-Run Decline. Economics History and Institutions Working Papers, Universidad Carlos III, Departamento de Historia Económica e Instituciones.

Prasad, E.S., Rogoff, K.S., Shang-Jin Wei. and M. A. Kose, 2004. Financial Globalization, Growth and Volatility in Developing Countries. NBER Working Paper 10942.

Ramey, G. and V. Ramey, 1995. Cross-country Evidence on the Link between Volatility and Growth. American Economic Review 85, 1138-1151.

Sanz-Villarroya, I. 2005. The Convergence Process of Argentina with Australia and Canada: 1875--2000. Explorations in Economic History 42, 439--458.

Sanz-Villarroya, I. 2007. La Belle Époque de la Economía Argentina. 1875-1913. Acciones e Investigaciones Sociales, 23, 115-138.

Taylor, A. 1992. External Dependence, Demographic Burdens and Argentine Economic Decline after the Belle Epoque. The Journal of Economic History 52(4), 907-936.

Taylor, A. 2003. Capital Formation: Saving, Investment, and Foreign Capital. In della Paolera, G. and Taylor, A. (Eds.), A New Economic History of Argentina.

Tornell, A., Westermann F. and L. Martinez, The Positive Link Between Financial Liberalization, Growth and Crises, NBER Working Paper No. 10293, 2004 
Figure 1. Ratio of Argentina's GDP per capita to Developed Countries' GDP per capita, 1885-2003

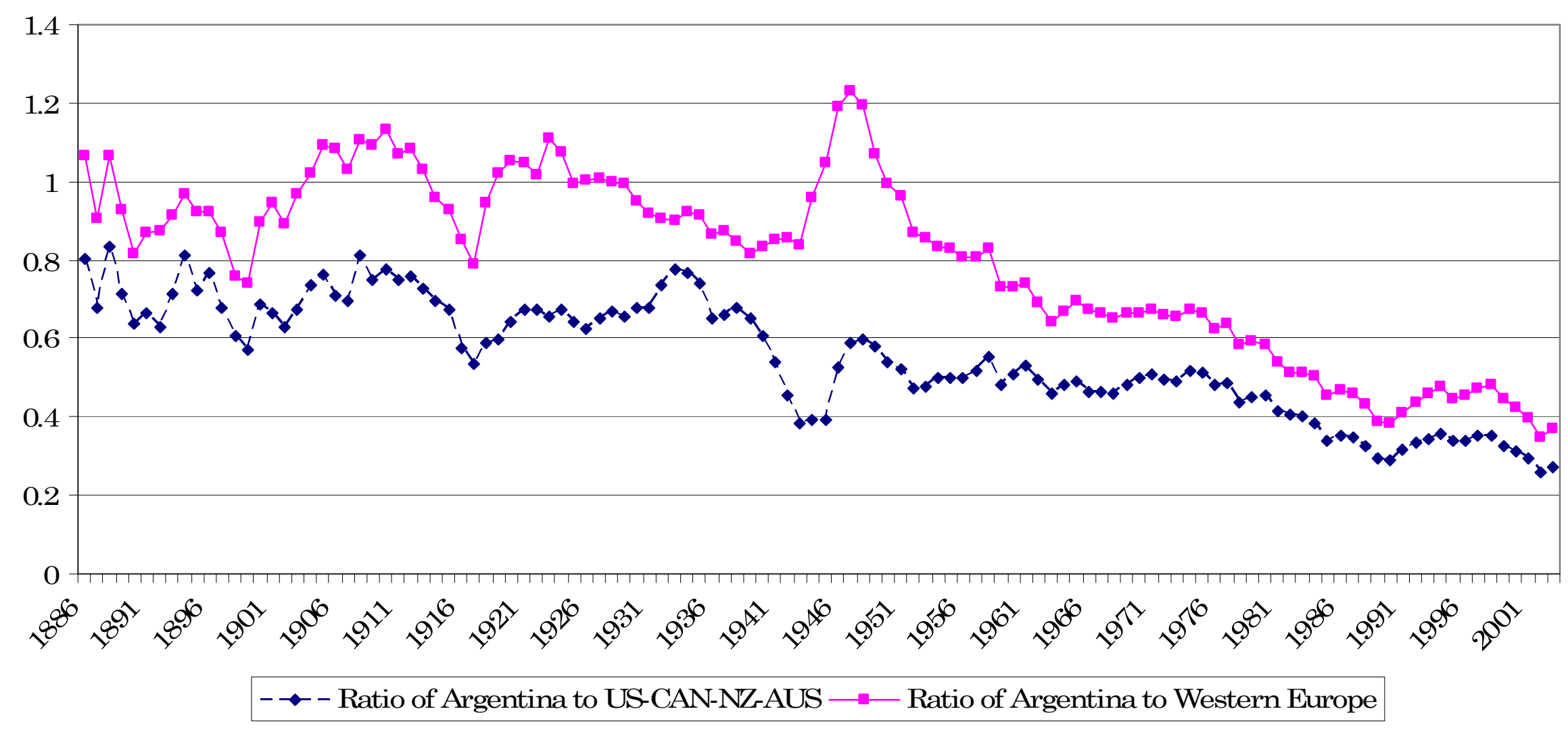

Note: Authors' calculations using GDP per capita data from Maddison (2007), Western Europe is Austria, Belgium, Denmark, Finland, France, Germany, Italy, Netherlands, Norway, Sweden, Switzerland and United Kingdom. The other group, Western Offshoots, includes Australia, Canada, New Zealand and United States. 
Figure 2. Measures of Financial Development
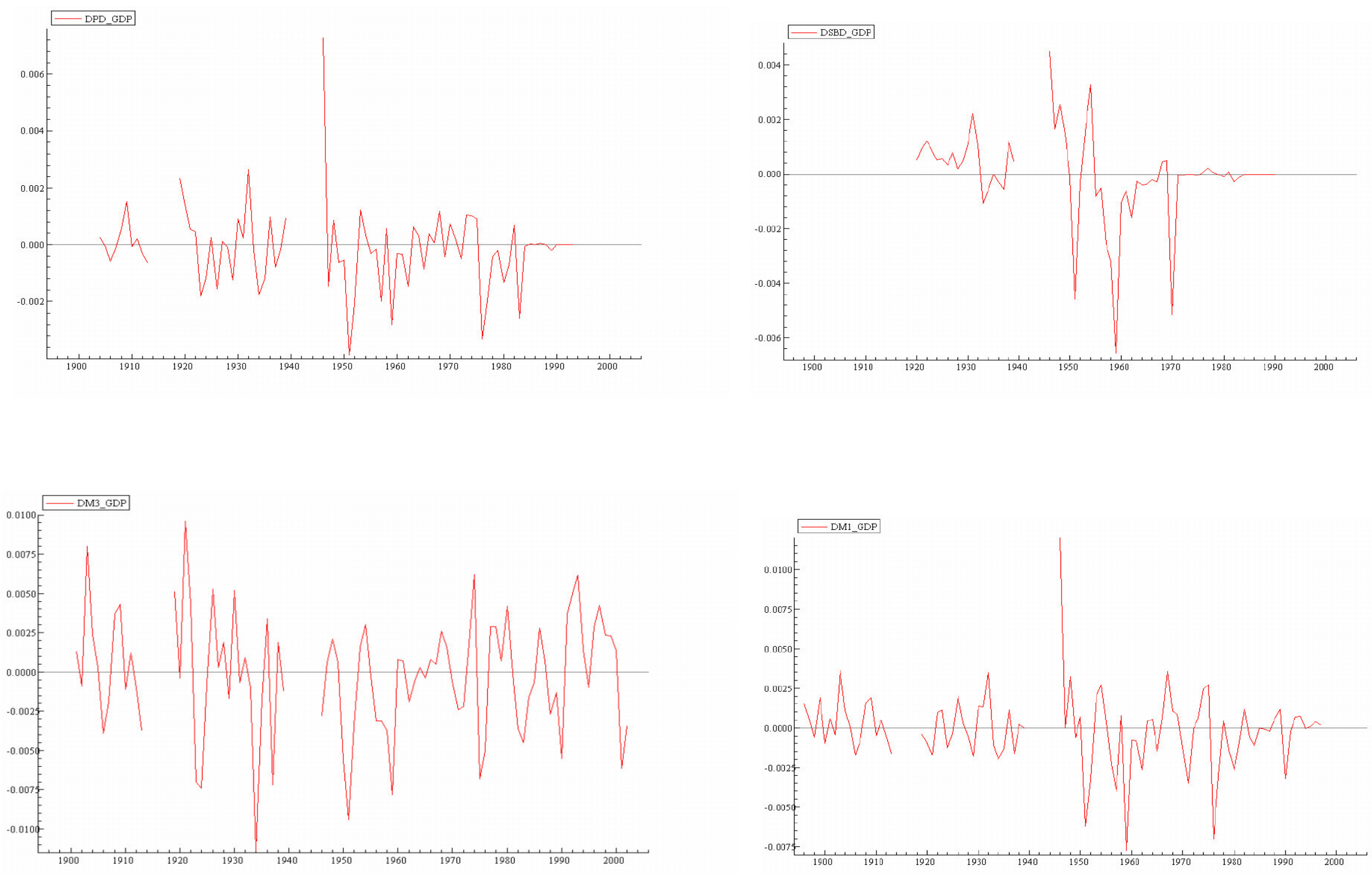

26 
Figure 3. Measures of Informal Political Instability
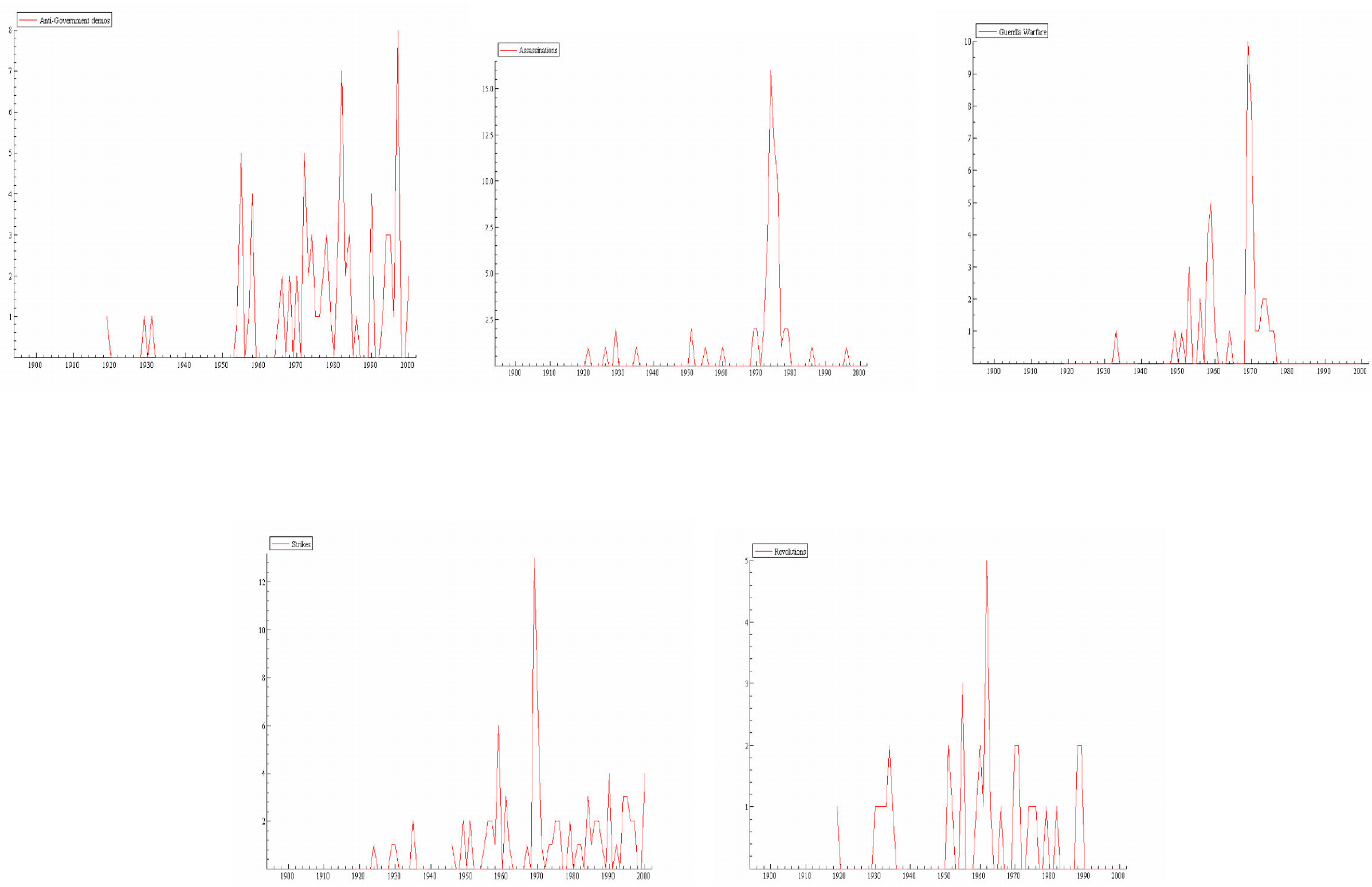


\section{Figure 4. Measures of Formal Political Instability}
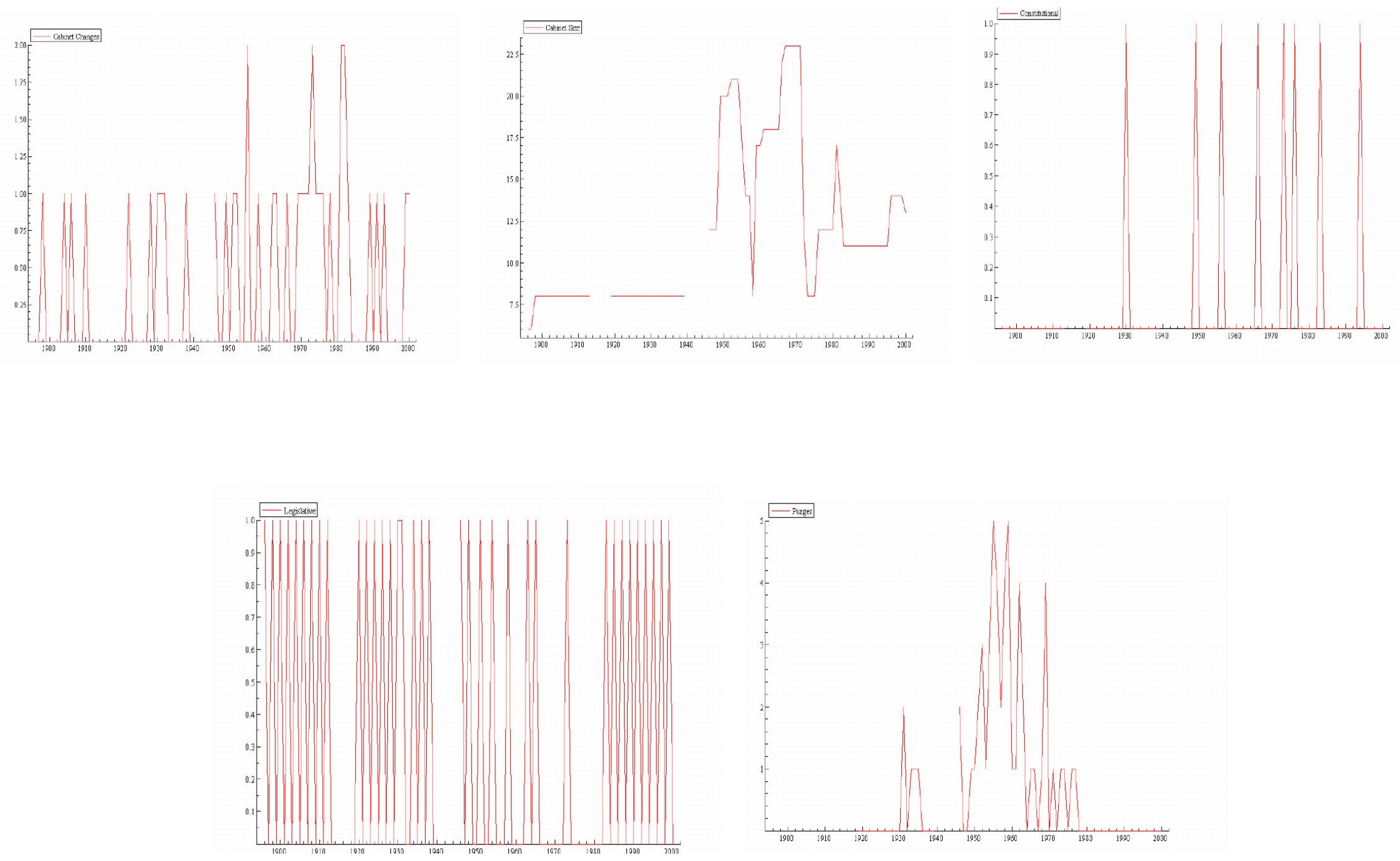
Figure 5. Autocorrelation of $\left|G_{-} P C I\right|^{d}$ from high to low

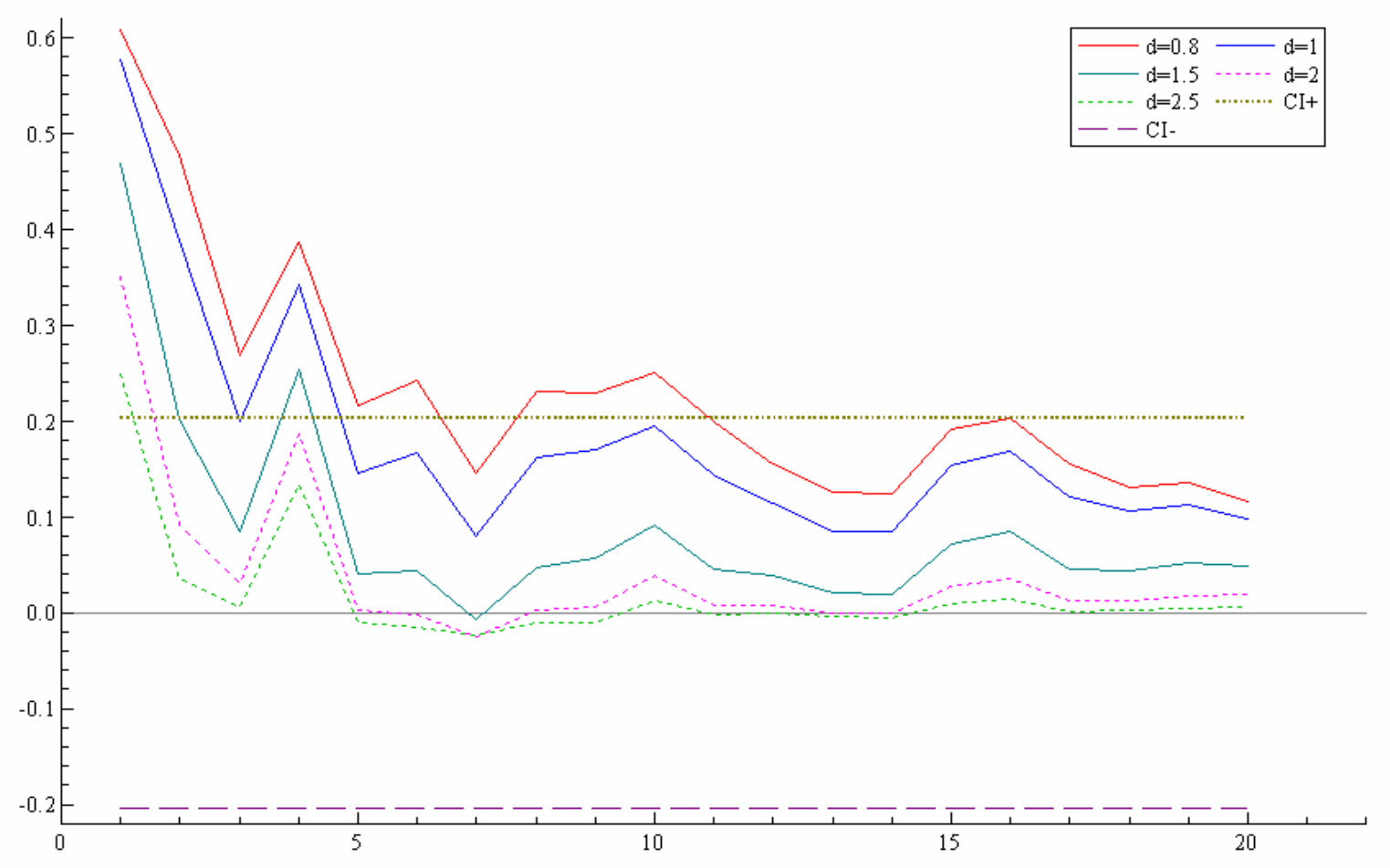


Table 1. Direct Effect of Political Instability/Financial

Development on Economic Growth, (P)ARCH estimates

\begin{tabular}{|c|c|c|c|c|c|}
\hline & $k$ & $\lambda$ & $\alpha$ & $\beta$ & $\delta$ \\
\hline \multicolumn{6}{|c|}{ Panel A. Informal Political Instability } \\
\hline Anti-Government Demos & $\begin{array}{l}1.00 \\
(1.66)\end{array}$ & $-\underset{(1.36)}{0.0010}$ & $\begin{array}{l}0.83 \\
(4.15)\end{array}$ & $\begin{array}{l}0.44 \\
(1.90)\end{array}$ & 1.00 \\
\hline Assassinations & $\begin{array}{l}1.38 \\
(1.85)\end{array}$ & $-\underset{(1.70)}{0.0014}$ & $\begin{array}{l}0.54 \\
(3.86)\end{array}$ & $\begin{array}{l}0.58 \\
(4.04)\end{array}$ & 0.90 \\
\hline Guerilla Warfare & $\begin{array}{l}1.00 \\
(3.69)\end{array}$ & $-\underset{(4.35)}{0.0013}$ & $\begin{array}{l}0.77 \\
(5.43)\end{array}$ & $\begin{array}{l}0.47 \\
(3.13)\end{array}$ & 0.90 \\
\hline Revolutions & $\begin{array}{l}0.99 \\
(4.31)\end{array}$ & $\underset{(0.14)}{0.0001}$ & $\begin{array}{l}0.61 \\
(5.17)\end{array}$ & $\begin{array}{l}0.59 \\
(4.95)\end{array}$ & 0.80 \\
\hline Strikes & $\begin{array}{l}0.99 \\
(3.07)\end{array}$ & -0.0012 & $\begin{array}{l}0.79 \\
(4.66)\end{array}$ & $\begin{array}{l}0.44 \\
(2.38)\end{array}$ & 0.90 \\
\hline \multicolumn{6}{|c|}{ Panel B. Formal Political Instability } \\
\hline Cabinet Changes & $\begin{array}{l}2.40 \\
(3.97)\end{array}$ & $\underset{(0.03)}{0.00005}$ & $\begin{array}{l}0.31 \\
(3.89)\end{array}$ & $\begin{array}{l}0.72 \\
(5.09)\end{array}$ & 0.80 \\
\hline Cabinet Size & $\begin{array}{l}0.79 \\
(1.78)\end{array}$ & $\underset{(1.47)}{0.0002}$ & $\begin{array}{l}0.90 \\
(4.13)\end{array}$ & $\begin{array}{l}0.46 \\
(2.32)\end{array}$ & 1.00 \\
\hline Constitutional & $\begin{array}{l}1.80 \\
(1.99)\end{array}$ & $-\underset{(1.35)}{-0.0027}$ & $\begin{array}{l}0.56 \\
(3.01)\end{array}$ & $\begin{array}{l}0.48 \\
(1.25)\end{array}$ & 0.80 \\
\hline Government Crises & $\begin{array}{l}1.03 \\
(2.53)\end{array}$ & $-\underset{(0.42)}{-0.0004}$ & $\begin{array}{l}0.65 \\
(4.89)\end{array}$ & $\begin{array}{l}0.54 \\
(3.59)\end{array}$ & 0.80 \\
\hline Legislative Elections & $\frac{1.91}{(2.69)}$ & $-\underset{(0.15)}{-0.0003}$ & $\begin{array}{l}0.38 \\
(3.43)\end{array}$ & $\begin{array}{l}0.69 \\
(5.79)\end{array}$ & 0.80 \\
\hline Purges & $\begin{array}{l}1.27 \\
(1.92)\end{array}$ & $\frac{-0.0010}{(1.55)}$ & $\begin{array}{r}0.58 \\
(4.03) \\
\end{array}$ & $\begin{array}{l}0.56 \\
(3.69) \\
\end{array}$ & 0.80 \\
\hline \multicolumn{6}{|l|}{ Panel C. Financial Development } \\
\hline Private Deposits/GDP & $\begin{array}{l}0.76 \\
(2.66)\end{array}$ & $\begin{array}{c}0.98 \\
(9.21)\end{array}$ & $\begin{array}{l}0.70 \\
(4.99)\end{array}$ & $\begin{array}{l}0.57 \\
(4.94)\end{array}$ & 0.80 \\
\hline Savings Bank Deposits/GDP & $\begin{array}{l}0.74 \\
(1.80)\end{array}$ & $\begin{array}{l}0.58 \\
(3.43)\end{array}$ & $\begin{array}{l}0.76 \\
(4.36)\end{array}$ & $\begin{array}{l}0.56 \\
(4.97)\end{array}$ & 0.80 \\
\hline $\mathrm{M} 3 / \mathrm{GDP}$ & $\begin{array}{l}0.81 \\
(1.94)\end{array}$ & $\begin{array}{l}0.32 \\
(1.71)\end{array}$ & $\begin{array}{l}0.94 \\
(3.76)\end{array}$ & $\begin{array}{l}0.43 \\
(2.04)\end{array}$ & 1.00 \\
\hline M1/GDP & $\begin{array}{c}0.69 \\
(2.30)\end{array}$ & $\begin{array}{r}0.58 \\
(5.14)\end{array}$ & $\begin{array}{l}0.75 \\
(5.29)\end{array}$ & $\begin{array}{l}0.56 \\
(5.85)\end{array}$ & 0.80 \\
\hline
\end{tabular}

Table 1 reports parameter estimates for the following model:

$y_{t}=c+k h_{t}+\lambda x_{i t}+\varepsilon_{t}, \quad h_{t}^{\frac{\delta}{2}}=\omega+\alpha h_{t-1}^{\frac{\delta}{2}}\left|e_{t-1}\right|^{\delta}+\beta h_{t-1}^{\frac{\delta}{2}}$.

The numbers in parentheses are absolute t statistics. 
Table 2. Indirect Effect of Political Instability/Financial Development on Economic Growth, (P)ARCH estimates

\begin{tabular}{|c|c|c|c|c|c|c|}
\hline & $k$ & $\alpha$ & $\beta$ & $\gamma$ & $\phi$ & $\delta$ \\
\hline \multicolumn{7}{|c|}{ Panel A. Informal Political Instability } \\
\hline Anti-Government Demos & $\begin{array}{l}1.25 \\
(2.56)\end{array}$ & $\begin{array}{l}0.65 \\
(4.52)\end{array}$ & $\begin{array}{l}0.46 \\
(5.94)\end{array}$ & $\begin{array}{l}0.17 \\
(4.51)\end{array}$ & $-\underset{(0.31)}{-0.0002}$ & 0.90 \\
\hline Assassinations & $\begin{array}{l}1.09 \\
(2.72)\end{array}$ & $\begin{array}{l}0.68 \\
(5.30)\end{array}$ & $\begin{array}{l}0.27 \\
(5.84)\end{array}$ & $\begin{array}{l}0.27 \\
(5.84)\end{array}$ & $\underset{(1.45)}{-0.0038}$ & 0.80 \\
\hline Guerilla Warfare & $\frac{1.12}{(2.46)}$ & $\begin{array}{l}0.73 \\
(4.80)\end{array}$ & $\begin{array}{l}0.46 \\
(4.00)\end{array}$ & $\begin{array}{l}0.10^{*} \\
(2.00)\end{array}$ & $\begin{array}{c}0.0007 \\
(0.82)\end{array}$ & 0.90 \\
\hline Revolutions & $\begin{array}{l}1.22 \\
(2.03)\end{array}$ & $\begin{array}{l}0.69 \\
(3.73)\end{array}$ & $\begin{array}{l}0.45 \\
(2.37)\end{array}$ & $\underbrace{0.11^{*}}_{(1.80)}$ & $-\underset{(0.14)}{-0.0002}$ & 0.80 \\
\hline Strikes & $\begin{array}{l}1.14 \\
(2.33)\end{array}$ & $\begin{array}{l}0.70 \\
(3.55) \\
\end{array}$ & $\begin{array}{l}0.48 \\
(2.69) \\
\end{array}$ & $\begin{array}{c}0.06^{*} \\
(1.73)\end{array}$ & $\begin{array}{c}0.0011 \\
(1.27) \\
\end{array}$ & 0.90 \\
\hline \multicolumn{7}{|c|}{ Panel B. Formal Political Instability } \\
\hline Cabinet Changes & $\begin{array}{l}1.28 \\
(1.96)\end{array}$ & $\begin{array}{l}0.55 \\
(2.99)\end{array}$ & $\begin{array}{l}0.53 \\
(4.90)\end{array}$ & $\begin{array}{l}0.21 \\
(3.93)\end{array}$ & $\underset{(4.03)}{-0.0050}$ & 1.00 \\
\hline Cabinet Size & $\begin{array}{l}1.14 \\
(1.77)\end{array}$ & $\begin{array}{l}0.60 \\
(3.89)\end{array}$ & $\begin{array}{l}0.54 \\
(5.02)\end{array}$ & $\begin{array}{l}0.18 \\
(2.48)\end{array}$ & $-\underset{(2.13)}{-0.0002}$ & 1.00 \\
\hline Constitutional & $\begin{array}{l}1.18 \\
(1.94)\end{array}$ & $\begin{array}{l}0.69 \\
(4.40)\end{array}$ & $\begin{array}{l}0.45 \\
(4.15)\end{array}$ & $\begin{array}{l}0.18 \\
(3.75)\end{array}$ & $-\underset{(3.40)}{-0.0077}$ & 1.00 \\
\hline Government Crises & $\begin{array}{l}1.12 \\
(2.30)\end{array}$ & $\begin{array}{l}0.72 \\
(4.59)\end{array}$ & $\begin{array}{l}0.47 \\
(3.28)\end{array}$ & $\underbrace{0.11^{*}}_{(2.44)}$ & $\begin{array}{c}0.0007 \\
(0.57)\end{array}$ & 0.90 \\
\hline Legislative Elections & $\begin{array}{l}1.46 \\
(2.52)\end{array}$ & $\begin{array}{l}0.62 \\
(4.70)\end{array}$ & $\begin{array}{l}0.44 \\
(3.52)\end{array}$ & $\begin{array}{l}0.20 \\
(3.12)\end{array}$ & $-\underset{(1.17)}{-0.0110}$ & 0.80 \\
\hline Purges & $\begin{array}{l}1.06 \\
(3.00) \\
\end{array}$ & $\begin{array}{l}0.75 \\
(5.26) \\
\end{array}$ & $\begin{array}{l}0.46 \\
(4.32) \\
\end{array}$ & $\begin{array}{l}0.09 \\
(1.99)\end{array}$ & $\begin{array}{c}0.0004 \\
(0.64)\end{array}$ & 0.90 \\
\hline \multicolumn{7}{|c|}{ Panel C. Financial Development } \\
\hline Private Deposits/ GDP & $\begin{array}{l}2.05 \\
(2.23)\end{array}$ & $\underset{(3.04)}{0.41}$ & $\begin{array}{l}0.62 \\
(6.75)\end{array}$ & $\begin{array}{l}0.40 \\
(5.69)\end{array}$ & $\begin{array}{l}0.58 \\
(0.53)\end{array}$ & 0.80 \\
\hline Savings Bank Deposits/ GDP & $\begin{array}{l}1.81 \\
(1.92)\end{array}$ & $\begin{array}{l}0.53 \\
(2.95)\end{array}$ & $\begin{array}{l}0.60 \\
(6.37)\end{array}$ & $\begin{array}{l}0.32^{\star} \\
(6.84)\end{array}$ & $\frac{-0.38}{(0.38)}$ & 0.80 \\
\hline M3/GDP & $\begin{array}{l}1.35 \\
(2.48)\end{array}$ & $\begin{array}{l}0.58 \\
(4.22)\end{array}$ & $\begin{array}{l}0.48 \\
(4.49)\end{array}$ & $\begin{array}{l}0.23 \\
(4.03)\end{array}$ & $\begin{array}{l}0.29 \\
(0.36)\end{array}$ & 0.80 \\
\hline M1/GDP & $\begin{array}{l}1.22 \\
(2.56) \\
\end{array}$ & $\begin{array}{l}0.49 \\
(5.30) \\
\end{array}$ & $\begin{array}{l}0.59 \\
(9.46)\end{array}$ & $\begin{array}{l}0.34 \\
(5.67) \\
\end{array}$ & $\begin{array}{c}-0.13 \\
(0.23) \\
\end{array}$ & 0.80 \\
\hline
\end{tabular}

Table 2 reports parameter estimates for the following model: $y_{t}=c+k h_{t}+\varepsilon_{t}, \quad h_{t}^{\frac{\delta}{2}}=\omega+\alpha h_{t-1}^{\frac{\delta}{2}}\left|e_{t-1}\right|^{\delta}+\beta h_{t-1}^{\frac{\delta}{2}}+\gamma_{6} y_{t-6}+\phi x_{i t}$.

** The orders of the lags are seven and five respectively.

The numbers in parentheses are absolute t statistics. 
Table 3. The short- and long-run effects of Political Instability /Financial Development on Economic Growth

\begin{tabular}{|c|c|c|c|c|c|c|}
\hline & $\theta_{l}$ & $\lambda$ & $\varphi$ & $\alpha$ & $\beta$ & $\delta$ \\
\hline \multicolumn{7}{|c|}{ Panel A. Informal Political Instability } \\
\hline Antigovernment & & & & & & 080 \\
\hline Demos & $\begin{array}{l}(2.92) \\
l=2\end{array}$ & $(1.04)$ & $(4.96)$ & $(7.17)$ & $(6.26)$ & -00 \\
\hline Assassinations & $-\underset{\substack{(2.46) \\
l=4}}{0.0019}$ & $\begin{array}{c}-0.0012 \\
(3.52)\end{array}$ & $\begin{array}{c}-0.71 \\
(3.89)\end{array}$ & $\begin{array}{l}0.82 \\
(5.68)\end{array}$ & $\begin{array}{l}0.53 \\
(9.10)\end{array}$ & 0.90 \\
\hline Guerilla Warfare & $\underset{\substack{(3.38) \\
l=3}}{-0.0014}$ & $-\underset{(2.59)}{-0.0007}$ & $\begin{array}{c}-0.60 \\
(7.20)\end{array}$ & $\begin{array}{l}1.10 \\
(4.19)\end{array}$ & $\begin{array}{l}0.36 \\
(3.59)\end{array}$ & 0.90 \\
\hline Revolutions & $\begin{array}{c}-0.0015 \\
\substack{2.13) \\
l=5}\end{array}$ & $\begin{array}{c}0.0013 \\
(2.37)\end{array}$ & $\begin{array}{c}-0.50 \\
(3.60)\end{array}$ & $\begin{array}{l}0.83 \\
(5.76)\end{array}$ & $\begin{array}{l}0.52 \\
(6.85)\end{array}$ & 0.80 \\
\hline Strikes & $\begin{array}{c}-0.0026 \\
(2.13) \\
l=4\end{array}$ & $-\underset{(2.74)}{0.0021}$ & $\begin{array}{c}-0.54 \\
(4.89)\end{array}$ & $\begin{array}{l}0.76 \\
(4.39)\end{array}$ & $\begin{array}{l}0.55 \\
(6.65)\end{array}$ & 0.80 \\
\hline \multicolumn{7}{|c|}{ Panel B. Financial Development } \\
\hline Private & & 0.94 & -0.44 & 0.37 & 0.80 & 0.90 \\
\hline Deposits/GDP & $\begin{array}{c}(1.81) \\
l=5\end{array}$ & & (0.1 & $(2.63)$ & & \\
\hline Savings Bank & -0.55 & 0.59 & -0.70 & 0.74 & 0.56 & 0.80 \\
\hline Deposits/GDP & $\begin{array}{c}(1.89) \\
l=1\end{array}$ & $(4.84)$ & & $(6.69)$ & $(6.21)$ & \\
\hline M3/GDP & $\begin{array}{c}-0.16 \\
(3.00) \\
l=4\end{array}$ & $\begin{array}{l}0.16 \\
(1.60)\end{array}$ & $\begin{array}{c}-0.83 \\
(4.11)\end{array}$ & $\begin{array}{l}0.81 \\
(6.59)\end{array}$ & $\begin{array}{l}0.52 \\
(7.19)\end{array}$ & 0.80 \\
\hline M1/GDP & $\begin{array}{c}-0.21 \\
(1.91) \\
l=1\end{array}$ & $\begin{array}{l}0.43 \\
(4.20)\end{array}$ & $\begin{array}{c}-0.85 \\
(4.14)\end{array}$ & $\begin{array}{l}0.74 \\
(6.89)\end{array}$ & $\begin{array}{l}0.54 \\
(6.62)\end{array}$ & 0.80 \\
\hline
\end{tabular}

Table 3 reports parameter estimates for the following model:

$\Delta y_{t}=\theta_{l} \Delta x_{i, t-l}+\phi\left(y_{t-1}-c-\lambda x_{i, t-1}\right)+u_{t}$, with $h_{t}^{\frac{\delta}{2}}=\omega+\alpha\left|u_{t-1}\right|^{\delta}+\beta h_{t-1}^{\frac{\delta}{2}} \cdot \theta_{l}(l$ is the order of the lag $)$ and

$\lambda$ capture the short- and long-run effects respectively. $\phi$ indicates the speed of adjustment to the long-run relationship.

The numbers in parentheses are absolute t statistics. 
Table 4. Direct Effect of Political Instability/Financial Development on Economic Growth, Dummies and (P)ARCH estimates

\begin{tabular}{|c|c|c|c|c|c|c|c|c|c|}
\hline & $k$ & $\gamma_{6}$ & $\lambda$ & $\lambda_{1}$ & $\omega_{1}$ & $\omega_{2}$ & $\alpha$ & $\beta$ & $\delta$ \\
\hline \multicolumn{10}{|c|}{ Panel A. Informal Political Instability } \\
\hline Anti-Government Demos & $\begin{array}{l}2.68 \\
(2.00)\end{array}$ & $\begin{array}{l}0.10 \\
(2.90)\end{array}$ & $\begin{array}{c}-0.003 \\
(0.50)\end{array}$ & $\underset{(0.62)}{0.003^{*}}$ & $\begin{array}{l}-0.02 \\
(1.44)\end{array}$ & $\begin{array}{l}0.04 \\
(3.40)\end{array}$ & $\begin{array}{l}0.42 \\
(3.20)\end{array}$ & $\begin{array}{l}0.42 \\
(3.21)\end{array}$ & 0.9 \\
\hline Assassinations & $\begin{array}{l}2.17 \\
(1.85)\end{array}$ & $\begin{array}{l}0.09 \\
(2.34)\end{array}$ & $\begin{array}{c}-0.002 \\
(0.16)\end{array}$ & - & - & $\begin{array}{l}0.04 \\
(3.29)\end{array}$ & $\begin{array}{l}0.48 \\
(4.24)\end{array}$ & $\begin{array}{l}0.37 \\
(3.52)\end{array}$ & 0.9 \\
\hline Guerilla Warfare & $\begin{array}{l}2.07 \\
(2.85)\end{array}$ & $\begin{array}{l}0.18 \\
(4.68)\end{array}$ & $\underset{(2.68)}{-0.001}$ & - & - & $\begin{array}{l}0.04 \\
(3.54)\end{array}$ & $\begin{array}{l}0.46 \\
(5.34)\end{array}$ & $\begin{array}{l}0.42 \\
(5.40)\end{array}$ & 0.8 \\
\hline Revolutions & $\begin{array}{l}1.71 \\
(2.63)\end{array}$ & $\begin{array}{l}0.25 \\
(5.70)\end{array}$ & $\begin{array}{c}0.002 \\
(4.19)\end{array}$ & $\begin{array}{c}-0.003 \\
(4.75)\end{array}$ & $\begin{array}{l}-0.04 \\
(1.82)\end{array}$ & $\begin{array}{l}0.07 \\
(3.52)\end{array}$ & $\begin{array}{l}0.57 \\
(5.40)\end{array}$ & $\begin{array}{l}0.11 \\
(1.12)\end{array}$ & 0.8 \\
\hline Strikes & $\begin{array}{l}2.17 \\
(1.71) \\
\end{array}$ & $\begin{array}{l}0.06 \\
(2.40)\end{array}$ & $\begin{array}{c}0.0002 \\
(0.38)\end{array}$ & $\begin{array}{c}-0.0013 \\
(1.78)\end{array}$ & - & $\begin{array}{l}0.03 \\
(3.44) \\
\end{array}$ & $\begin{array}{l}0.49 \\
(3.74) \\
\end{array}$ & $\begin{array}{l}0.41 \\
(4.00)\end{array}$ & 1.0 \\
\hline \multicolumn{10}{|c|}{ Panel B. Formal Political Instability } \\
\hline Cabinet Changes & $\begin{array}{l}2.41 \\
(2.25)\end{array}$ & $\begin{array}{l}0.10 \\
(1.90)\end{array}$ & $\begin{array}{c}0.0007 \\
(1.05)\end{array}$ & - & $\begin{array}{c}-0.02 \\
(1.53)\end{array}$ & $\begin{array}{l}0.06 \\
(4.21)\end{array}$ & $\begin{array}{l}0.41 \\
(3.69)\end{array}$ & $\begin{array}{l}0.36 \\
(4.11)\end{array}$ & 0.8 \\
\hline Cabinet Size & $\begin{array}{l}2.12 \\
(3.01)\end{array}$ & $\begin{array}{l}0.16 \\
(4.56)\end{array}$ & $-\underset{(1.24)}{0.0006}$ & $0_{(0.89)}^{0.0003}$ & $\underset{(1.56)}{-0.02}$ & $\begin{array}{l}0.05 \\
(4.01)\end{array}$ & $\begin{array}{l}0.44 \\
(4.09)\end{array}$ & $\begin{array}{l}0.42 \\
(5.03)\end{array}$ & 0.8 \\
\hline Constitutional & $\begin{array}{l}2.24 \\
2.13\end{array}$ & $\begin{array}{l}0.10 \\
(1.99)\end{array}$ & $\frac{0.0007}{(0.50)}$ & - & $\begin{array}{c}-0.02 \\
(1.70)\end{array}$ & $\begin{array}{l}0.06 \\
(4.21)\end{array}$ & $\begin{array}{l}0.43 \\
(3.28)\end{array}$ & $\begin{array}{l}0.36 \\
(2.74)\end{array}$ & 0.8 \\
\hline Government Crises & $\begin{array}{l}2.10 \\
(1.70)\end{array}$ & $\begin{array}{l}0.10 \\
(4.70)\end{array}$ & $-\underset{(1.14)}{0.0009}$ & $-\underset{(1.08)}{0.0009}$ & - & $\begin{array}{l}0.03 \\
(2.85)\end{array}$ & $\begin{array}{l}0.50 \\
(3.86)\end{array}$ & $\begin{array}{l}0.40 \\
(3.95)\end{array}$ & 1.0 \\
\hline Legislative Elections & $\begin{array}{l}1.53 \\
(1.69)\end{array}$ & $\begin{array}{l}0.22 \\
(4.17)\end{array}$ & $\begin{array}{c}0.001 \\
(1.27)\end{array}$ & $\begin{array}{c}-0.003 \\
(1.41)\end{array}$ & - & $\begin{array}{l}0.02 \\
(1.38)\end{array}$ & $\begin{array}{l}0.50 \\
(3.53)\end{array}$ & $\begin{array}{l}0.47 \\
(5.38)\end{array}$ & 1.0 \\
\hline Purges & $\begin{array}{l}2.43 \\
(1.93) \\
\end{array}$ & $\begin{array}{l}0.08 \\
(6.51)\end{array}$ & $\begin{array}{c}0.001 \\
(1.59)\end{array}$ & $\begin{array}{c}-0.002 \\
(2.87) \\
\end{array}$ & - & $\begin{array}{l}0.03 \\
(3.26) \\
\end{array}$ & $\begin{array}{l}0.40 \\
(3.23) \\
\end{array}$ & $\begin{array}{l}0.48 \\
(6.20) \\
\end{array}$ & 1.0 \\
\hline \multicolumn{10}{|c|}{ Panel C. Financial Development } \\
\hline Private Deposits/GDP & $\begin{array}{l}2.26 \\
(2.64)\end{array}$ & $\begin{array}{l}0.11 \\
(1.79)\end{array}$ & $\begin{array}{l}0.90 \\
(4.03)\end{array}$ & - & $\frac{-0.02}{(1.58)}$ & $\begin{array}{l}0.05 \\
(4.33)\end{array}$ & $\begin{array}{l}0.36 \\
(2.72)\end{array}$ & $\begin{array}{l}0.50 \\
(4.04)\end{array}$ & 0.8 \\
\hline Savings Bank Deposits/GDP & $\begin{array}{l}3.75 \\
(3.05)\end{array}$ & $\begin{array}{l}0.04 \\
(2.03)\end{array}$ & $\begin{array}{l}0.63 \\
(2.34)\end{array}$ & - & - & $\begin{array}{l}0.03 \\
(4.52)\end{array}$ & $\begin{array}{l}0.51 \\
(4.50)\end{array}$ & $\begin{array}{l}0.45 \\
(5.13)\end{array}$ & 1.0 \\
\hline $\mathrm{M} 3 / \mathrm{GDP}$ & $\begin{array}{l}2.96 \\
(1.89)\end{array}$ & $\begin{array}{l}0.04 \\
(1.23)\end{array}$ & $\begin{array}{l}0.09 \\
(0.35)\end{array}$ & - & $\begin{array}{c}-0.01 \\
(1.52)\end{array}$ & $\begin{array}{l}0.04 \\
(3.50)\end{array}$ & $\begin{array}{l}0.38 \\
(2.86)\end{array}$ & $\begin{array}{l}0.43 \\
(3.19)\end{array}$ & 1.0 \\
\hline $\mathrm{M} 1 / \mathrm{GDP}$ & $\begin{array}{l}2.70 \\
(2.15) \\
\end{array}$ & $\begin{array}{l}0.06 \\
(1.71) \\
\end{array}$ & $\begin{array}{l}0.51 \\
(2.85) \\
\end{array}$ & - & $\begin{array}{c}-0.02 \\
(1.65)\end{array}$ & $\begin{array}{l}0.05 \\
(3.99) \\
\end{array}$ & $\begin{array}{l}0.39 \\
(3.09) \\
\end{array}$ & $\begin{array}{l}0.43 \\
(3.40) \\
\end{array}$ & 0.9 \\
\hline
\end{tabular}

Table 4 reports parameter estimates for the following model:

$y_{t}=c+k h_{t}+\lambda x_{i t}+\lambda_{1} D_{i t} x_{i t}+\varepsilon_{t}$,

$h_{t}^{\frac{\delta}{2}}=\omega+\omega_{1} D_{1 t}+\omega_{2} D_{2 t}+\alpha h_{t-1}^{\frac{\delta}{2}}\left|e_{t-1}\right|^{\delta}+\beta h_{t-1}^{\frac{\delta}{2}}+\gamma_{6} y_{t-6}$.

The numbers in parentheses are absolute t statistics.

${ }^{*}$ We include a second dummy $\left(D_{i t}\right)$ with estimated coefficient $0.0006(0.10)$. 
Table 5. Indirect Effect of Political Instability/Financial Development on Economic Growth, Dummies and (P)ARCH estimates

\begin{tabular}{|c|c|c|c|c|c|c|c|c|c|}
\hline & $k$ & $\gamma_{6}$ & $\phi$ & $\phi_{1}$ & $\omega_{1}$ & $\omega_{2}$ & $\alpha$ & $\beta$ & $\delta$ \\
\hline \multicolumn{10}{|c|}{ Panel A. Informal Political Instability } \\
\hline Anti-Government Demos & $\begin{array}{l}2.06 \\
(2.08)\end{array}$ & $\begin{array}{l}0.06 \\
(1.21)\end{array}$ & $\underset{(0.53)}{0.006}$ & $\begin{array}{l}-0.005^{*} \\
(0.43)\end{array}$ & - & $\begin{array}{l}0.04 \\
(2.05)\end{array}$ & $\begin{array}{l}0.50 \\
(3.32)\end{array}$ & $\begin{array}{l}0.42 \\
(3.06)\end{array}$ & 0.9 \\
\hline Assassinations & $\begin{array}{l}2.08 \\
(3.22)\end{array}$ & $\begin{array}{l}0.18 \\
(4.07)\end{array}$ & $\underset{(1.11)}{-0.002}$ & - & $\begin{array}{c}-0.03 \\
(1.31)\end{array}$ & $\begin{array}{l}0.05 \\
(4.38)\end{array}$ & $\begin{array}{l}0.46 \\
(4.74)\end{array}$ & $\begin{array}{l}0.36 \\
(3.22)\end{array}$ & 0.8 \\
\hline Guerilla Warfare & $\begin{array}{l}2.43 \\
(1.71)\end{array}$ & $\begin{array}{l}0.08 \\
(1.54)\end{array}$ & $\underset{(1.01)}{0.001}$ & - & $\frac{-0.03}{(1.85)}$ & $\begin{array}{l}0.05 \\
(3.98)\end{array}$ & $\begin{array}{l}0.43 \\
(3.44)\end{array}$ & $\begin{array}{l}0.39 \\
(3.18)\end{array}$ & 0.9 \\
\hline Revolutions & $\begin{array}{l}1.93 \\
(1.91)\end{array}$ & $\begin{array}{l}0.20 \\
(6.49)\end{array}$ & $\frac{-0.002}{(2.57)}$ & $\underset{(0.62)}{0.001}$ & $\begin{array}{c}-0.03 \\
(2.34)\end{array}$ & $\begin{array}{l}0.05 \\
(4.03)\end{array}$ & $\begin{array}{l}0.52 \\
(4.49)\end{array}$ & $\begin{array}{l}0.23 \\
(2.83)\end{array}$ & 0.9 \\
\hline Strikes & $\begin{array}{l}2.38 \\
(2.27) \\
\end{array}$ & $\begin{array}{l}0.06 \\
(1.73)\end{array}$ & $\begin{array}{c}0.001 \\
(0.09)\end{array}$ & $\begin{array}{c}0.001 \\
(1.33)\end{array}$ & - & $\begin{array}{l}0.04 \\
(2.95)\end{array}$ & $\begin{array}{l}0.41 \\
(3.31) \\
\end{array}$ & $\begin{array}{l}0.47 \\
(4.14)\end{array}$ & 0.9 \\
\hline \multicolumn{10}{|c|}{ Panel B. Formal Political Instability } \\
\hline Cabinet Changes & $\begin{array}{l}2.29 \\
(1.73)\end{array}$ & $\begin{array}{l}0.12 \\
(4.44)\end{array}$ & $\underset{(4.39)}{-0.003}$ & - & $\begin{array}{l}-0.01 \\
(1.51)\end{array}$ & $\begin{array}{l}0.04 \\
(4.03)\end{array}$ & $\begin{array}{l}0.43 \\
(3.18)\end{array}$ & $\begin{array}{l}0.33 \\
(2.98)\end{array}$ & 1.0 \\
\hline Cabinet Size & $\begin{array}{l}2.73 \\
(1.83)\end{array}$ & $\begin{array}{l}0.04 \\
(1.56)\end{array}$ & $\begin{array}{c}-0.001 \\
(1.79)\end{array}$ & $\underset{(1.58)}{0.0004}$ & $\frac{-0.01}{(1.66)}$ & $\begin{array}{l}0.04 \\
(4.25)\end{array}$ & $\begin{array}{l}0.36 \\
(3.00)\end{array}$ & $\begin{array}{l}0.47 \\
(5.06)\end{array}$ & 1.0 \\
\hline Constitutional & $\begin{array}{l}2.84 \\
(2.22)\end{array}$ & $\begin{array}{l}0.07 \\
(3.30)\end{array}$ & $\frac{-0.02}{(4.60)}$ & - & $\begin{array}{c}-0.10 \\
(1.42)\end{array}$ & $\begin{array}{l}0.03 \\
(3.57)\end{array}$ & $\begin{array}{l}0.30 \\
(2.21)\end{array}$ & $\begin{array}{l}0.53 \\
(5.10)\end{array}$ & 1.0 \\
\hline Government Crises & $\begin{array}{l}2.75 \\
(2.25)\end{array}$ & $\begin{array}{c}0.008 \\
(0.03)\end{array}$ & $\underset{(1.80)}{-0.002}$ & $\begin{array}{c}-0.003 \\
(3.50)\end{array}$ & - & $\begin{array}{l}0.04 \\
(3.30)\end{array}$ & $\begin{array}{l}0.33 \\
(2.66)\end{array}$ & $\begin{array}{l}0.55 \\
(4.74)\end{array}$ & 0.9 \\
\hline Legislative Elections & $\begin{array}{l}1.97 \\
(2.23)\end{array}$ & $\begin{array}{l}0.12 \\
(2.67)\end{array}$ & $\begin{array}{c}-0.01 \\
(1.69)\end{array}$ & $\begin{array}{c}-0.005 \\
(2.43)\end{array}$ & - & $\begin{array}{l}0.02 \\
(1.21)\end{array}$ & $\begin{array}{l}0.49 \\
(3.66)\end{array}$ & $\begin{array}{l}0.46 \\
(3.14)\end{array}$ & 0.9 \\
\hline Purges & $\begin{array}{l}1.96 \\
(1.38) \\
\end{array}$ & $\begin{array}{l}0.15 \\
(5.02) \\
\end{array}$ & $\begin{array}{c}0.003 \\
(1.57)\end{array}$ & $\begin{array}{c}-0.002 \\
(1.11)\end{array}$ & $\begin{array}{c}-0.04 \\
(2.30) \\
\end{array}$ & $\begin{array}{l}0.06 \\
(3.79) \\
\end{array}$ & $\begin{array}{l}0.55 \\
(5.05) \\
\end{array}$ & $\begin{array}{l}0.21 \\
(2.37) \\
\end{array}$ & 0.9 \\
\hline \multicolumn{10}{|l|}{ Panel C. Financial Development } \\
\hline Private Deposits/GDP & $\begin{array}{l}2.89 \\
(2.19)\end{array}$ & $\begin{array}{l}0.12 \\
(1.89)\end{array}$ & $\begin{array}{l}0.02 \\
(0.02)\end{array}$ & - & $\begin{array}{c}-0.03 \\
(1.71)\end{array}$ & $\begin{array}{l}0.07 \\
(4.07)\end{array}$ & $\begin{array}{l}0.37 \\
(2.80)\end{array}$ & $\begin{array}{l}0.39 \\
(2.16)\end{array}$ & 0.8 \\
\hline Savings Bank Deposits/GDP & $\underset{(1.71)}{2.37}$ & $\begin{array}{l}0.16 \\
(3.23)\end{array}$ & $\begin{array}{c}-0.57 \\
(0.61)\end{array}$ & - & - & $\begin{array}{l}0.05 \\
(3.24)\end{array}$ & $\begin{array}{l}0.35 \\
(2.43)\end{array}$ & $\begin{array}{l}0.54 \\
(3.37)\end{array}$ & 0.8 \\
\hline $\mathrm{M} 3 / \mathrm{GDP}$ & $\begin{array}{l}1.78 \\
(2.33)\end{array}$ & $\begin{array}{l}0.24 \\
(3.13)\end{array}$ & $\begin{array}{l}0.59 \\
(0.61)\end{array}$ & - & - & $\begin{array}{l}0.04 \\
(1.95)\end{array}$ & $\begin{array}{l}0.62 \\
(1.66)\end{array}$ & $\begin{array}{l}0.29 \\
(2.31)\end{array}$ & 0.8 \\
\hline $\mathrm{M} 1 / \mathrm{GDP}$ & $\begin{array}{l}2.73 \\
(2.73) \\
\end{array}$ & $\begin{array}{l}0.13 \\
(2.87) \\
\end{array}$ & $\begin{array}{c}-0.16 \\
(0.17) \\
\end{array}$ & - & $\begin{array}{c}-0.02 \\
(1.64) \\
\end{array}$ & $\begin{array}{l}0.06 \\
(3.74) \\
\end{array}$ & $\begin{array}{l}0.40 \\
(3.16) \\
\end{array}$ & $\begin{array}{l}0.38 \\
(2.53) \\
\end{array}$ & 0.8 \\
\hline
\end{tabular}

Table 5 reports parameter estimates for the following model:

$y_{t}=c+k h_{t}+\varepsilon_{t}$,

$h_{t}^{\frac{\delta}{2}}=\omega+\omega_{1} D_{1 t}+\omega_{2} D_{2 t}+\alpha h_{t-1}^{\frac{\delta}{2}}\left|e_{t-1}\right|^{\delta}+\beta h_{t-1}^{\frac{\delta}{2}}+\gamma_{6} y_{t-6}+\phi x_{i t}+\phi_{1} D_{i t} x_{i t}$.

The numbers in parentheses are absolute $t$ statistics.

${ }^{*}$ We include a second dummy $\left(D_{i t}\right)$ with estimated coefficient $-0.007(1.06)$. 
Table 6. The short- and long-run effects of Political Instability/Financial

Development on Economic Growth, Dummies and (P)ARCH estimates

\begin{tabular}{|c|c|c|c|c|c|c|c|c|c|}
\hline & $\theta_{l}$ & $\lambda$ & $\varphi$ & $\alpha$ & $\beta$ & $\delta$ & $\omega_{1}$ & $\omega_{2}$ & $\gamma_{6}$ \\
\hline \multicolumn{10}{|c|}{ Panel A. Informal Political Instability } \\
\hline $\begin{array}{l}\text { Antigovernment } \\
\text { Demos }\end{array}$ & $-\underset{\substack{(1.92) \\
l=1}}{0.0010}$ & $\begin{array}{c}-0.0006 \\
(0.93)\end{array}$ & $\begin{array}{c}-0.37 \\
(3.62)\end{array}$ & $\begin{array}{l}0.47 \\
(2.05)\end{array}$ & $\begin{array}{l}0.48 \\
(2.70)\end{array}$ & 0.90 & - & $\begin{array}{l}0.03 \\
(1.68)\end{array}$ & $\begin{array}{l}0.12 \\
(3.97)\end{array}$ \\
\hline Assassinations & $-\underset{\substack{(1.90) \\
l=4}}{0.0018}$ & $\underset{(0.54)}{0.0004}$ & $\begin{array}{c}-0.31 \\
(3.36)\end{array}$ & $\begin{array}{l}0.52 \\
(2.15)\end{array}$ & $\begin{array}{l}0.39 \\
(2.14)\end{array}$ & 0.90 & - & $\begin{array}{l}0.04 \\
(2.28)\end{array}$ & $\begin{array}{c}-0.01 \\
(0.27)\end{array}$ \\
\hline Guerilla Warfare & $-\underset{\substack{(1.61) \\
l=6}}{0.0012}$ & $\begin{array}{c}-0.0008 \\
(2.46)\end{array}$ & $\begin{array}{c}-0.27 \\
(3.11)\end{array}$ & $\begin{array}{l}0.62 \\
(3.20)\end{array}$ & $\begin{array}{l}0.30 \\
(2.31)\end{array}$ & 0.90 & - & $\begin{array}{l}0.04 \\
(2.69)\end{array}$ & $\begin{array}{l}0.04 \\
(0.83)\end{array}$ \\
\hline Revolutions & $-\underset{\substack{(1.77) \\
l=0}}{0.0004}$ & $\begin{array}{c}-0.0002 \\
(0.37)\end{array}$ & $\frac{-0.22}{(2.10)}$ & $\begin{array}{l}0.57 \\
(2.35)\end{array}$ & $\begin{array}{l}0.28 \\
(2.83)\end{array}$ & 0.90 & $\begin{array}{c}-0.03 \\
(1.54)\end{array}$ & $\begin{array}{l}0.06 \\
(3.85)\end{array}$ & $\begin{array}{c}-0.05 \\
(1.25)\end{array}$ \\
\hline Strikes & $\begin{array}{c}-0.0012 \\
\substack{(1.96) \\
l=6} \\
\end{array}$ & $\begin{array}{c}-0.0012 \\
(2.35)\end{array}$ & $\begin{array}{l}-0.28 \\
(2.83)\end{array}$ & $\begin{array}{l}0.62 \\
(3.49)\end{array}$ & $\begin{array}{l}0.30 \\
(2.18)\end{array}$ & 0.80 & - & $\begin{array}{l}0.06 \\
(2.43)\end{array}$ & $\begin{array}{l}0.04 \\
(0.53)\end{array}$ \\
\hline \multicolumn{10}{|c|}{ Panel B. Financial Development } \\
\hline $\begin{array}{l}\text { Private } \\
\text { Deposits/GDP }\end{array}$ & $\underset{\substack{(3.22) \\
l=5}}{-0.29}$ & $\begin{array}{l}0.90 \\
(3.50)\end{array}$ & $\begin{array}{c}-0.26 \\
(2.16)\end{array}$ & $\begin{array}{l}0.45 \\
(1.79)\end{array}$ & $\begin{array}{l}0.31 \\
(2.81)\end{array}$ & 0.90 & $\begin{array}{c}-0.03 \\
(1.96)\end{array}$ & $\begin{array}{l}0.07 \\
(4.87)\end{array}$ & $\begin{array}{c}-0.02 \\
(0.47)\end{array}$ \\
\hline $\begin{array}{l}\text { Savings Bank } \\
\text { Deposits/GDP }\end{array}$ & $\underset{\substack{(3.55) \\
l=5}}{-0.54}$ & $\begin{array}{l}0.60 \\
(2.57)\end{array}$ & $\begin{array}{c}-0.26 \\
(2.27)\end{array}$ & $\begin{array}{l}0.58 \\
(3.18)\end{array}$ & $\begin{array}{l}0.41 \\
(1.91)\end{array}$ & 0.80 & - & $\begin{array}{l}0.05 \\
(1.71)\end{array}$ & $\begin{array}{l}0.06 \\
(0.66)\end{array}$ \\
\hline M3/GDP & $\begin{array}{c}0.08 \\
\left(\begin{array}{c}0.58) \\
l=4\end{array}\right.\end{array}$ & $\begin{array}{l}0.11 \\
(0.58)\end{array}$ & $\begin{array}{l}-0.23 \\
(2.26)\end{array}$ & $\begin{array}{l}0.55 \\
(2.03)\end{array}$ & $\begin{array}{l}0.30 \\
(3.10)\end{array}$ & 1.00 & $\begin{array}{c}-0.02 \\
(1.60)\end{array}$ & $\begin{array}{l}0.04 \\
(4.02)\end{array}$ & $\begin{array}{l}-0.03 \\
(1.00)\end{array}$ \\
\hline M1/GDP & $\begin{array}{c}-0.21 \\
(2.78) \\
l=5\end{array}$ & $\begin{array}{l}0.35 \\
(1.89)\end{array}$ & $\begin{array}{l}-0.28 \\
(2.73)\end{array}$ & $\begin{array}{l}0.45 \\
(2.03)\end{array}$ & $\begin{array}{l}0.34 \\
(3.27)\end{array}$ & 0.80 & $\begin{array}{c}-0.03 \\
(2.07)\end{array}$ & $\begin{array}{l}0.07 \\
(4.93)\end{array}$ & $\begin{array}{c}-0.04 \\
(0.69)\end{array}$ \\
\hline
\end{tabular}

Table 6 reports parameter estimates for the following model:

$\Delta y_{t}=\theta_{l} \Delta x_{i, t-l}+\varphi\left(y_{t-1}-c-\lambda x_{i, t-1}\right)+u_{t}$, with

$h_{t}^{\frac{\delta}{2}}=\omega+\omega_{1} D_{1 t}+\omega_{2} D_{2 t}+\alpha\left|u_{t-1}\right|^{\delta}+\beta h_{t-1}^{\frac{\delta}{2}}+\gamma_{6} y_{t-6}$.

$\theta_{l}$ ( $l$ is the order of the lag) and $\lambda$ capture the short- and

long-run effects respectively. $\varphi$ indicates the speed of

adjustment to the long-run relationship.

The numbers in parentheses are absolute t statistics. 